\title{
Ustyurtiidae, a new family of Urodoidea with description of a new genus and two species from Kazakhstan, and discussion on possible affinity of Urodoidea to Schreckensteinioidea (Lepidoptera)
}

\author{
Lauri Kaila $^{\text {a,*, Kari Nupponen }}{ }^{\text {b }}$, Pavel Yu. Gorbunov', Marko Mutanen ${ }^{\text {d }}$ and \\ Maria Heikkiläa \\ aFinnish Museum of Natural History, Zoology Unit, FI-00014 University of Helsinki, Finland. \\ E-mails: lauri.kaila@helsinki.fi; maria.heikkila@helsinki.fi \\ ${ }^{b}$ Merenneidontie 19 D, FI-02320 Espoo, Finland. E-mail: kari.nupponen@kolumbus.fi \\ ${ }^{\mathrm{C}}$ Institute of Ecology of Plants and Animals, Ural Division of Russian Academy of Sciences, \\ RU-620144 Ekaterinburg, Russia. E-mail: pg18@yandex.ru \\ ${ }^{\mathrm{d}}$ Department of Ecology and Genetics, PO Box 3000, 90014 University of Oulu, Finland. \\ E-mail: marko.mutanen@oulu.fi \\ *Corresponding author, e-mail: lauri.kaila@helsinki.fi
}

Version of Record, published online 5 March 2019; published in print 19 May 2020

\begin{abstract}
Ustyurtiidae Kaila, Heikkilä \& Nupponen, a new family of Urodoidea is introduced. The family is based on the genus Ustyurtia Kaila, Heikkilä \& Nupponen, gen. n. The genus includes the type species $U$. zygophyllivora Kaila, Heikkilä \& Nupponen, sp. n. and U. charynica Kaila, Heikkilä \& Nupponen, sp. n., both from Kazakhstan. These two species, in particular the immature stages, have morphological attributes apomorphic of Urodoidea. The close affinity is also supported by DNA data based on several markers. We consider this new family warranted due to its sister group position to the remaining Urodoidea and a number of significant morphological differences in wing venation, male genitalia and the structure of the cocoon, apomorphic for Ustyurtiidae on the basis of an earlier published phylogeny. All other recognized genera of Urodoidea belong to the family Urodidae. The closest relatives and phylogenetic position of Urodoidea are not firmly established, but Urodoidea and Schreckensteinioidea have morphological similarities which, in the light of genetic analyses appear synapomorphic and possibly uniting these groups, rather than homoplasious as assumed earlier. The affinities of these superfamilies are discussed.
\end{abstract}

\section{Keywords}

Ditrysia; phylogenetics; morphology; Zygophyllum; Ustyurtia

ZooBank: http://zoobank.org/332A4A52-B141-4354-8C27-4D0301CE35A0 


\section{Introduction}

Urodidae (false burnet moths) is a small family of apoditrysian moths placed in its own superfamily Urodoidea with no other families (Kyrki 1988). It currently contains ca 80 described species placed into eight genera. Five of these genera, Urodus Herrich-Schäffer, 1854; Spiladarcha Meyrick, 1913; Anchimacheta Walsingham, 1914; Incawockia Heppner, 2010; and Anomalomeuta Sohn, 2013 are found in the New World, with greatest species richness in South and Central America. The distribution of Wockia Heinemann, 1870 is Holarctic, Oriental, and Neotropical. Geoesthia Sohn, 2014 and Glaucotunica Sohn, 2014 are Asian. The adult moths are generally grey or brown in colour and the wingspan is $11-37 \mathrm{~mm}$. The known larvae construct a meshed cocoon that is generally atypical in Lepidoptera, but is also found in Plutellidae (Yponomeutoidea), Choreutidae (Choreutoidea) and Schreckensteiniidae (Schreckensteinioidea). The known larvae also possess some characteristic morphological features, such as sculpturing on the mentum, and medially narrowed prolegs. The biology of most species, however, remains unknown (Dugdale et al. 1998; Sohn 2014b).

\section{Review of taxonomic history of Urodidae}

Historically, genera currently in the family Urodidae were placed in Yponomeutoidea. However, basing his observations on species of the genera Urodus, Wockia and Spiladarcha, Kyrki $(1984,1988)$ demonstrated that there is no close relationship between these genera and yponomeutoids as had been suggested by e.g. Friese (1966) and Moriuti (1977). Kyrki (1988) erected the family Urodidae in the absence of any known plausible family with which to merge the 'Urodus group' sensu Kyrki (1984). He also suggested to place Urodidae in its own superfamily Urodoidea (Kyrki 1988). No comprehensive phylogenetic study (morphological or molecular) to resolve the relationships among the eight urodid genera has yet been made. Kyrki (1988) proposed six possible autapomorphies for the family:

1) Lamellate male antennae. In this case, the term lamellate seems to refer to laterally flattened and serrate or dentate type of antenna rather than lamellate in the sense found, for example, in many Sesiidae and Cossidae where the segments are plate-like (Edwards et al. 1998). Sohn \& Park (2009) use term "laminate". Sohn (2014b) pointed out that antennal lamellae are often inconspicuous in genera other than Urodus, and that the antennae of for example Incawockia and Glaucotunica are filiform, not lamellate (Sohn 2014b, 2014c).

2) Costal hair-pencil on male hind wing. Such hair-pencils are present in Urodus, Wockia and Incawockia but are absent in Spiladarcha, Anchimacheta, Anomalomeuta, Geoesthia and Glaucotunica (Sohn 2014b).

Sohn (2014b), who described several new genera and species of Urodidae, has suggested further characters, which, when present in combination, are according to him often diagnostic of adult moths of the family: naked haustellum; forewing discal cell 
bent downwards on distal $1 / 2$; forewing vein Rs4 directed to apex; forewing veins $\mathrm{CuA}_{1}$ and $\mathrm{CuA}_{2}$ sinuous; and the hind tibia with long hair-like scales. Other adult characters often present in Urodidae include patches of erect scales on the dorsal side of forewings and scale tufts on the ventral side of the $2^{\text {nd }}$ segment of the labial palpi. All the previously described genera have more or less identical wing venation with all veins separate and a distinct accessory cell (presence of chorda) in the forewing.

As Sohn (2014b) remarked, larvae of six of the eight described urodid genera are unknown. Thus, the presence of the four larval autapomorphies proposed by Kyrki (1988) has not been confirmed in Incawockia, Spiladarcha, Anchimacheta, Anomalomeuta, Geoesthia and Glaucotunica:

3) Larval prothorax without seta MXD1.

4) Larval abdominal segment VIII with L3 ventroanterior to L1 and L2.

5) SV1 almost as high as L3.

6) Larval prolegs elongate, medially constricted, crochets in mesoseries.

The systematic position of Urodoidea among basal Apoditrysia and the closest relatives of the superfamily remain unclear. This part of the lepidopteran phylogeny is the most unstable section of the tree as compared to early-diverging lineages (nonditrysians) and the Pyraloidea + macroheteroceran clade (e.g. Mitter et al. 2017). In addition, comparison of results of recent phylogenetic analyses exploring the evolutionary relationships among ditrysian Lepidoptera is not easy as the studies differ in their taxon sampling. The families which Urodidae have been associated with in these studies are Alucitidae, Choreutidae, Pterophoridae, Schreckensteiniidae or Tortricidae, mostly with low support values (Regier et al. 2009; Mutanen et al. 2010; Cho et al. 2011; Bazinet et al. 2013; Kawahara \& Breinholt 2014; Heikkilä et al. 2015). Regier et al. (2009) suggested that Urodidae were the sister group of either Alucitidae, Choreutidae or Tortricidae (Schreckensteinioidea were not included in the study). In Cho et al. (2010), Urodidae were either placed near Tortricidae, Alucitidae, Pterophoridae or Choreutidae (Schreckensteinioidea were not included). Urodidae were sister to all other Apoditrysia in Regier et al. (2013) (Pterophoridae and Alucitidae were not included). In Bazinet et al. (2013), Urodidae were sister to Choreutidae (Alucitidae and Schreckensteinioidea not included), and in Kawahara \& Breinholt (2014) sister to Pterophoridae (Alucitidae, Choreutidae and Schreckensteinioidea not included). In the only studies in which all the above-mentioned families were included (Mutanen et al. 2010 with 8 gene regions, and Heikkilä et al. 2015 with data from 8 gene regions and 530 morphological characters combined), Urodidae were the sister group of Schreckensteinioidea (Fig. 1), but with low support values (Mutanen et al. 2010: bootstrap $<50 \%$, posterior probability 0.47 , and Heikkilä et al. 2015: bootstrap 50\%). The affinity of Urodidae with Schreckensteinia (Schreckensteinioidea) had been suggested earlier but was not accepted by Minet (1983) and Kyrki (1988), who argued that the characters on which this hypothesis was based - elongate prolegs, reduced pupal spinosity and the meshed cocoon - are homoplasious.

The study by Heikkilä et al. (2015) included an undescribed genus and species from Kazakhstan that proved to belong to Urodoidea. We describe this taxon in the present work along with another species belonging to the same genus, collected at 


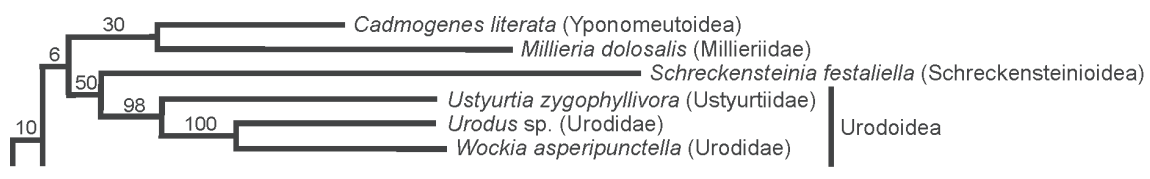

0.2

Fig. 1. Phylogenetic relationships among Ustyurtia, Urodus and Wockia as obtained in Heikkilä et al. (2015). Note the place of Schreckensteinia festaliella as the sister group to the included Urodidae. Numbers above branches indicate bootstrap support values.

another location in Kazakhstan. We discuss the affinity of this genus to other urodoids and evaluate the family-level autapomorphies proposed by Kyrki (1988). The discovery of the immature stages of one of the newly described species, Ustyurtia zygophyllivora Kaila, Heikkilä \& Nupponen, gen. n. and sp. n. allows the evaluation of the proposed larval and pupal autapomorphies. To accommodate this new genus and the two species, which differ considerably from other Urodidae in their morphology and both nuclear and mitochondrial DNA, we introduce a new family, Ustyurtiidae Kaila, Heikkilä \& Nupponen, fam. n.

In the light of the thorough morphological study of the adult and immatures stages, we will also assess if there is any morphological evidence supporting the possible relatedness of Urodoidea to Schreckensteinioidea, as obtained in the results by Mutanen et al. (2010) and Heikkilä et al. (2015).

Schreckensteinioidea is a small apoditrysian superfamily distributed to both Old and New World, characterized by narrow wings and stiff dorsal spines on the hind tibia. It consists of two genera, Schreckensteinia Hübner, 1825 and Corsocasis Meyrick, 1912. The closest relatives of Schreckensteinioidea are unknown. Proposed affinities with Yponomeutoidea, Copromorphoidea or Urodidae have been argued against by Minet (1983) and Kyrki (1984).

\section{Material and Methods}

\section{Study of morphology}

As a basis for the study of morphology a dataset created by Heikkilä et al. (2015, available at MorphoBank (Project 2183, https://morphobank.org/index.php/Projects/ ProjectOverview/project_id/2183), consisting of 530 coded characters was used. Further characters applicable to Urodoidea were also sought for. Specimens and slides were examined with Leica M125 and Wild M10 stereomicroscopes and Leitz Diaplan phase contrast compound microscope.

Immature stage character comparison is based on larvae and pupae of Ustyurtia zygophyllivora sp. n., Wockia asperipunctella (Bruand, 1852), Urodus parvula (Edwards, 1881) and Schreckensteinia festaliella (Hübner, 1819).

For comparative work of adult morphology, males and females of Ustyurtia zygophyllivora, Wockia asperipunctella, Urodus parvula and Schreckensteinia festaliella were examined. For Ustyurtia charynica, only males were available. Information on the 
adult morphology of the other urodid genera and species was obtained from literature (Clarke 1965; Dugdale et al. 1998; Sohn \& Park 2009; Sohn 2012, 2013, 2014a, b, c; Sinev 2016).

Terminology used follows Hinton (1946), Kyrki (1988) and Stehr (1987) for larval and pupal characters, Kyrki (1988) for genitalia and Wootton (1979) for wing venation.

\section{Phylogenetic study}

The phylogenetic study was based on eight gene regions previously demonstrated to be of high information content in Lepidoptera phylogenetics (Mutanen et al. 2010; Zahiri et al. 2010; Sihvonen et al. 2011; Kaila et al. 2011; Heikkilä et al. 2015): Cytochrome oxidase subunit I (COI), Elongation factor-1a (EF-1a), Ribosomal protein S5 (RpS5), Carbamoyl phosphate synthetase domain protein (CAD), Cytosolic malate dehydrogenase (MDH), Isocitrate dehydrogenase (IDH), wingless, and Glyceraldehyde-3- phosphate dehydrogenase (GAPDH) (Wahlberg \& Wheat 2008). For further details of molecular methods, see Heikkilä et al. (2015), who also included Ustyurtia in the maximum likelihood tree of the combined morphological and molecular data (in this work under the name "Urodidae sp.").

The COI sequences for the two specimens of Ustyurtia were generated following the standard DNA barcoding protocols described by deWaard et al. (2008). The full taxonomic, collection and sequence data for these specimens are available from the public BOLD dataset "Records of Ustyurtia (Lepidoptera, Urodidae, Ustyurtiinae" (DS-USTYU)") under the doi: http://dx.doi.org/10.5883/DS-USTYU.

Abbreviations of collection names: $\mathrm{MZH}=$ Finnish Museum of Natural History, University of Helsinki, Finland; ZIN = Zoological Institute of the Russian Academy of Sciences, St. Petersburg, Russia.

\section{Results and Discussion}

\section{What makes Ustyurtia an urodoid?}

In the phylogenetic study based on combined molecular (eight gene regions) and morphological data (530 characters) by Heikkilä et al. (2015), then undescribed Ustyurtia zygophyllivora grouped together with the other two included urodoids, Urodus parvula (Edwards) and Wockia asperipunctella (Bruand) with strong bootstrap support (98\%) (Fig. 1). The morphological support for this association, presented in Heikkilä et al. (2015), came in particular from the immature stages and is discussed in detail below. As noted in the introduction, adult characters common to all genera assigned to Urodoidea are few. Of the two autapomorphic adult characters proposed by Kyrki (1988), only the lamellate male antennae can be said to be present in the two newly described species, not in a conspicuous way, but rather as laterally flattened and dentate antennae, which also is the case in most other urodid genera. The basal hair-pencil on the male hind wing is absent, but so it is in urodids other than Urodus, Wockia and 

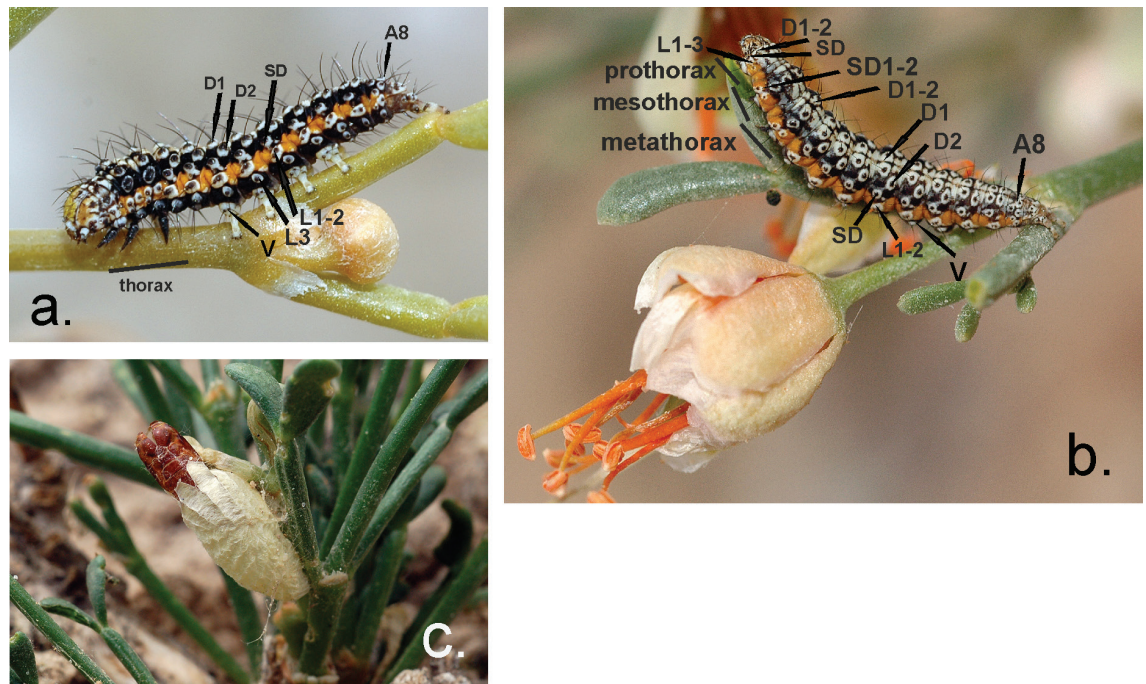

b.

Fig. 2. Ustyurtia zygophyllivora sp. n., a. larva in lateral view, displaying the elongate prolegs; b. larva in dorsal aspect. Explanations of abbreviations: D1-2 = dorsal setae 1 and 2, SD = subdorsal setal group, L1-3 = lateral setae, D2 = dorsal seta 2, A8 = segment 8 of abdomen, L1-2 = lateral setae 1 and 2, $\mathrm{V}=$ ventral setal group; $\mathbf{c}$. cocoon and pupal exuvia.

Incawockia. The female ovipositor of U. zygophyllivora is extensile as in other urodids, yet also in, e.g., Cossoidea-Sesioidea among apoditrysian Lepidoptera. Of the character combination diagnostic of many urodids identified by Sohn (2014b) only two characters, the unscaled haustellum and the forewing vein Rs4 directed to apex, are present in the newly described species. However, these characters are also present in many, if not most, other Microlepidoptera grade Lepidoptera, and are not diagnostic as such. Unlike most Urodidae (Sohn 2014b), in Ustyurtia the forewing discal cell is not bent downwards in distal $1 / 2$, the forewing veins $\mathrm{CuA}_{1}$ and $\mathrm{CuA}_{2}$ are not particularly sinuous and the hind tibiae do not have long hair-like scales such as in many urodids. New adult characters autapomorphic for the superfamily Urodoidea were not discovered during the morphological examination of the denuded adult male and female specimens of Ustyurtia, Wockia and Urodus.

In addition to molecular support for a close affinity of Ustyurtia to Urodidae, support comes in particular from characters of the immature stages. Of the four autapomorphies proposed by Kyrki (1988), the presence of elongate, medially constricted larval prolegs with very prominent proleg-bearing swellings on segments A3-6, as well as crochets in mesoseries are confirmed for Ustyurtia (Figs 2a, 3). The seta SV1 is positioned almost as high as L3 on larval abdominal segment VIII as stated by Kyrki for Wockia, but SV1 is positioned significantly more dorsally than L3, unlike in Wockia where they are almost at level.

The larvae of Ustyurtia zygophyllivora construct a shelter. It is similar to the meshed cocoon of other known urodids, but reinforced by a dense and stiff layer of silk, likely for protection against direct exposure to sun and heat (Fig. 2c). 


\section{Connections of Ustyurtia to urodoid genera}

A comprehensive phylogenetic analysis including representatives of all urodoid genera remains to be done, and currently the relationships among the nine genera are unknown. In Heikkilä et al. (2015), Ustyurtia is sister to the two other urodoid genera in the analysis, Wockia and Urodus. The genetic distance between Ustyurtia and the other urodoid genera for which genetic data are available is considerable (see Heikkilä et al. 2015). COI barcode data of 170 specimens of Urodidae accessible to us in BOLD database (www.boldsystems.org) indicate Kimura 2-parameter genetic distances as high as $11.2 \%-17.8 \%$ between Ustyurtia and the other genera of Urodidae (Urodus and Wockia). We consider these genetic distances and differences in the morphology as support for our decision to introduce a new family for the newly described genus and two species.

The adult morphology of Ustyurtiidae differs from that of Urodidae for example in wing venation (e.g. by the absence of an accessory cell; Fig. 8), which appears more uniform among the eight other urodoid genera, and could indicate that they are more closely related to each other. Differences were also found in the structure of sternum II and in the genitalia. In Ustyurtia, there are no anterolateral projections on the apodemes of sternum II, whereas these are present in, e.g., Wockia (Figs 9a, b), Anomalomeuta
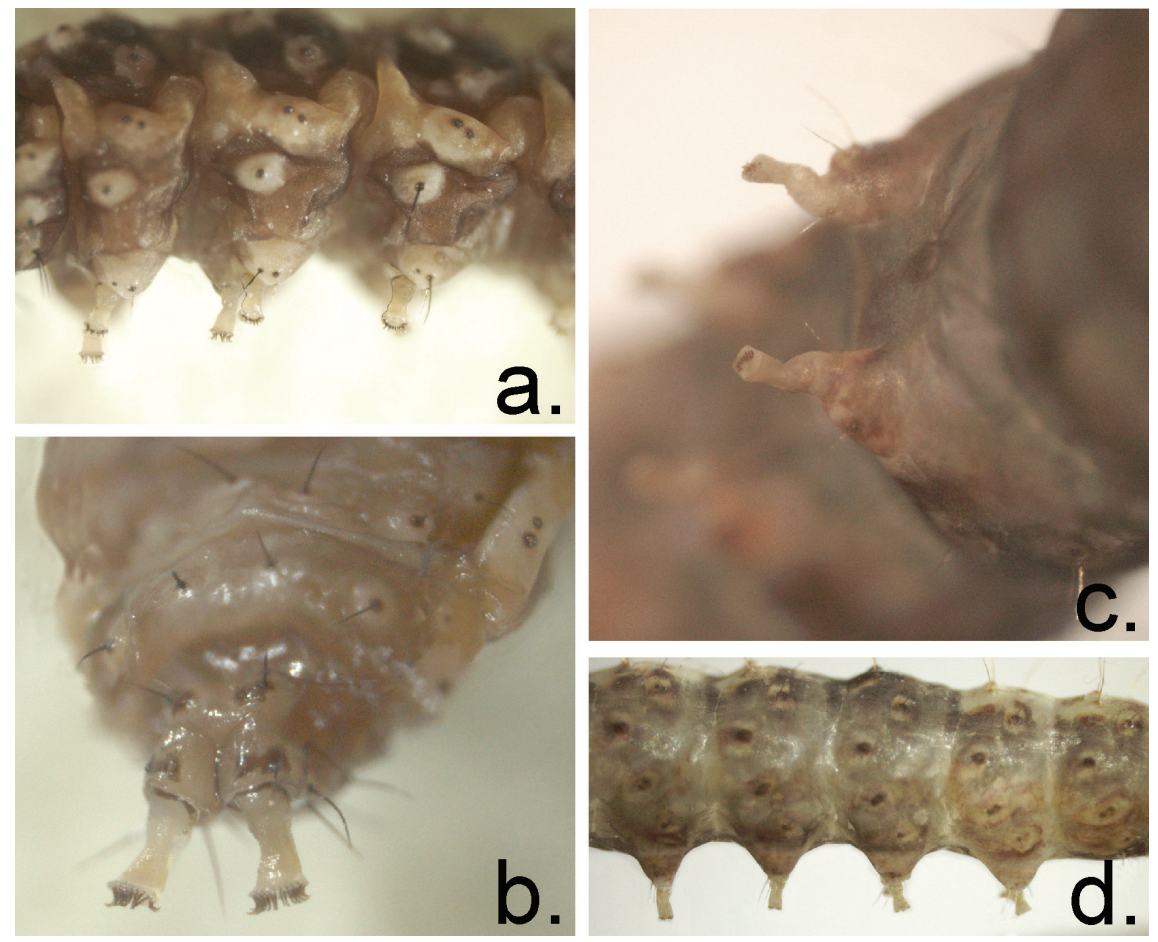

Fig. 3. Larval prolegs of Ustyurtia zygophyllivora sp. n. and Wockia asperipunctella. a. U. zygophyllivora, prolegs on abdominal segments 3-5; b. U. zygophyllivora, anal prolegs on abdominal segment 10 in ventral view; c. and $\mathbf{d}$. Wockia asperipunctella, larval prolegs, c. ventrolateral view, $\mathbf{d}$. lateral view. 

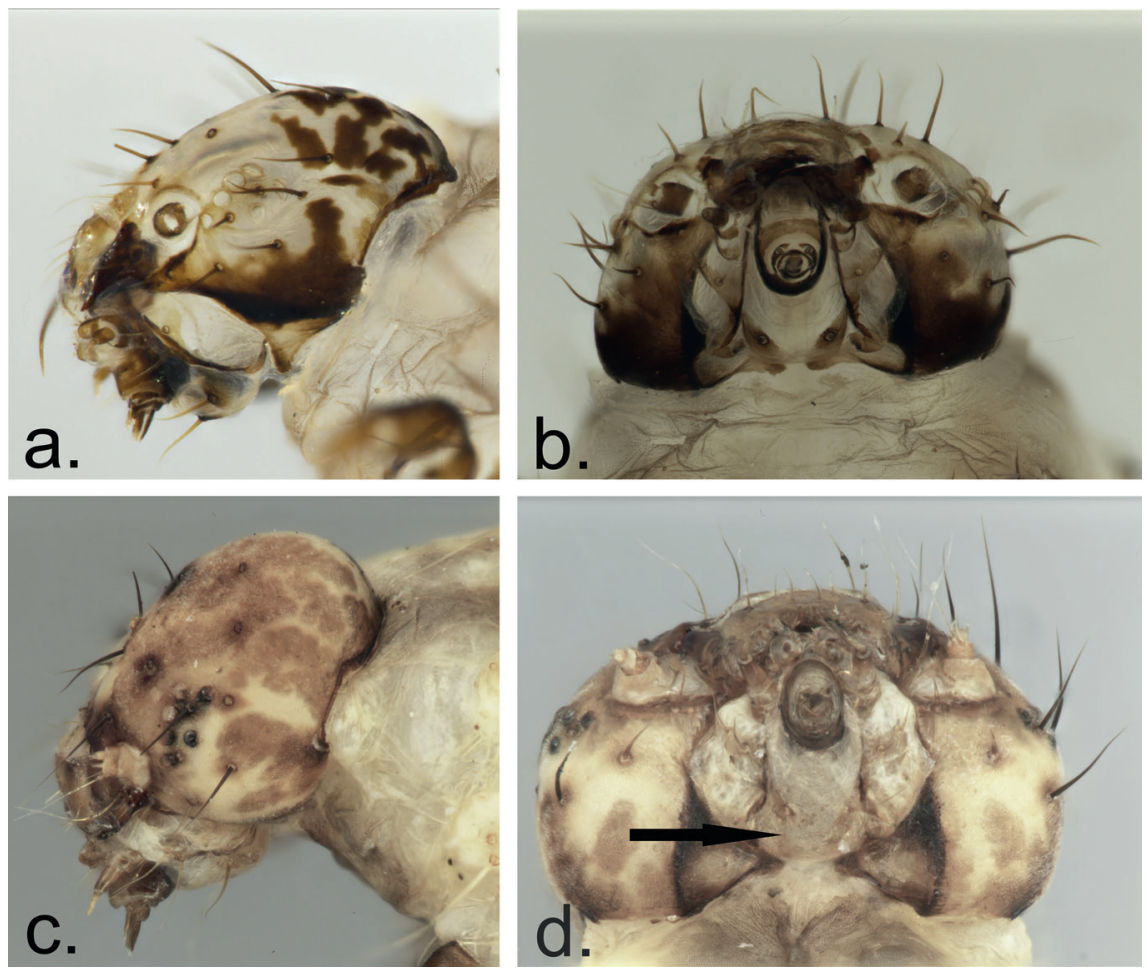

Fig. 4. Larval head. Arrows point at the sculpturing on mentum. a. and b. Ustyurtia zygophyllivora sp. n., a. lateral view; b. ventral view; c. and d. Wockia asperipunctella, c. lateral view; d. ventral view.

(Sohn 2013: 471, Fig. 3) and Anchimacheta (Sohn 2014b: 2619, fig. 1E). The genital capsule of males of the Ustyurtia species is strongly sclerotized and the genitalia cannot be spread on a regular microscope slide (Figs 10, 13). In other Urodoidea, the genital capsule is significantly less sclerotized and valvae are movable (J.-C. Sohn, pers. comm.). The shape of the uncus in Ustyurtia is also very different from that of the other Urodoidea. In Ustyurtia, the uncus is long and narrow, whereas in other Urodoidea it is of a more conical shape, shorter and broader, sometimes even absent or membranous. The two species of Ustyurtia also have a very long saccus that is absent in other Urodoidea. No obvious similarities, other than the already mentioned extensile ovipositor, were recorded in the female genitalia of $U$. zygophyllivora and the other Urodoidea.

Inferring phylogenetic relationships among urodoid genera from immature stage characters is preliminary as only the larvae and pupae of Ustyurtia zygophyllivora, and some, but not all species of Wockia and Urodus are known. Immature stages of more urodoids need to be studied to infer phylogenetic relationships, but based on our observations of the three species examined, it seems that Ustyurtia has more immature stage characters in common with Urodus than Wockia. Larval characters that U. zygophyllivora shares with Urodus include a head with rugose sculpturing. Granulose sculpturing of the larval mentum is characteristic to all known urodoid larvae but is a rare trait in other Lepidoptera (see below). Both Ustyurtia zygophyllivora and Urodus have rough stiff setomorph pubescence on the pupa outside the cremaster area. Ustyurtia 

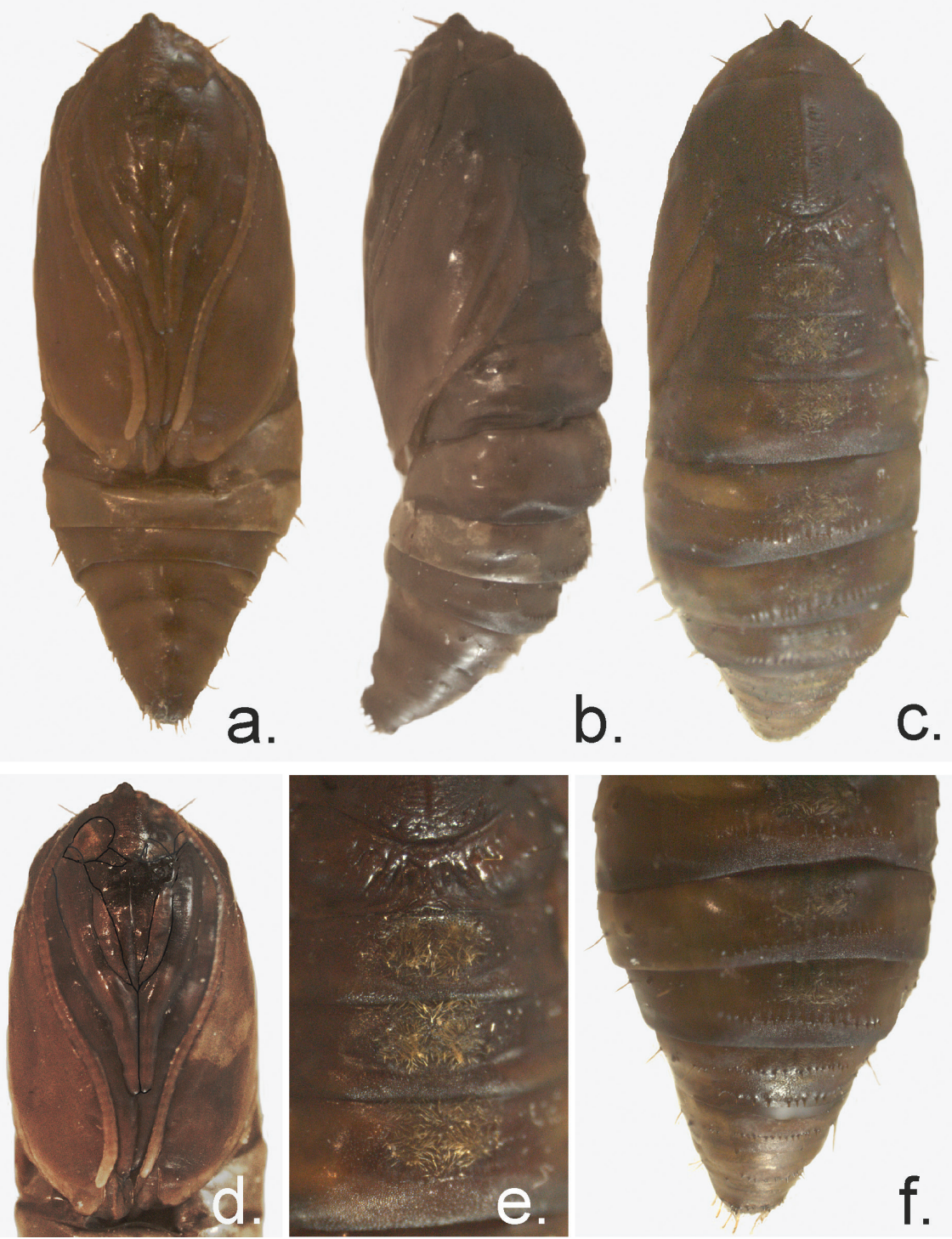

Fig. 5. Pupa of Ustyurtia zygophyllivora sp. n., a. whole pupa in ventral view; b. lateral view; c. dorsal view; $\mathbf{d}$. head and thorax; e. dorsal hair coverage on abdominal segments $1-3$; $\mathbf{f}$. dorsolateral view of abdominal segments 3-10 showing spine rows and primary setae.

and Urodus also share a forward-directed protuberance on the cephalic part of the pupal clypeus and a regular row of spines near the dorsocephalic margin of the segments of the pupal abdomen.

\section{Connection between Urodoidea and Schreckensteinioidea}

Inclusion of Ustyurtiidae in the phylogenetic studies by Mutanen et al. (2010) and Heikkilä et al. (2015) (Fig. 1) cut the long branch leading to Urodidae, which may contribute in stabilizing the position of the superfamily in the lepidopteran phylogeny. 

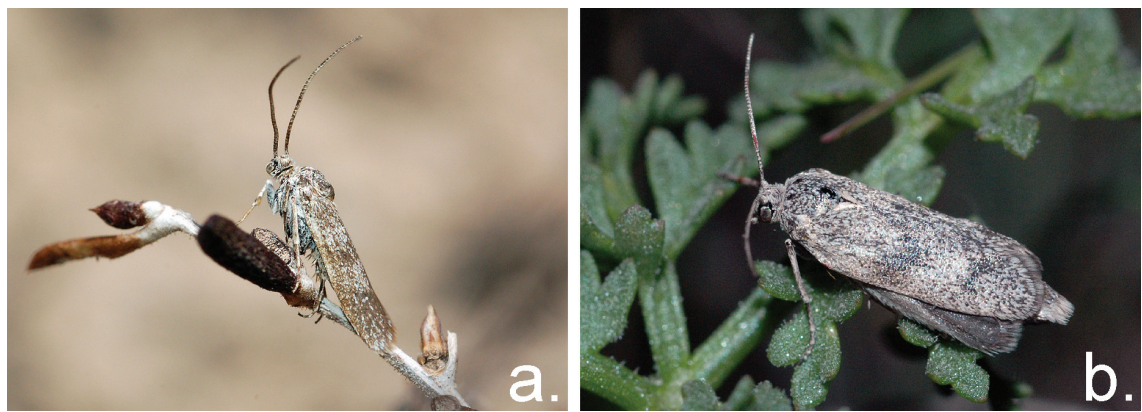

Fig. 6. Adults of Ustyurtia zygophyllivora sp. n. in their natural posture, a. male; b. female.

Because a sister group relationship between Schreckensteinioidea and Urodoidea was obtained in these two studies (Fig. 1), we here comment on the morphological features that unite and separate these groups, with notes on the occurrence of these characters in other ditrysian Lepidoptera. The observations are based on the morphological data matrix of Heikkilä et al. (2015).

Larval characters that unite Schreckensteinioidea and Urodoidea are:

Larval head retractile. This cannot be considered a particularly strong trait, as it is a fairly widespread condition through the microlepidopteran grade Lepidoptera, most often associated with internal feeders, such as in the Cossoidea-Zygaenoidea complex. Observing the presence of this character in dry, inflated larval samples may also be impossible to establish unambiguously.

The approximation of larval stemmata (Figs 2a; 13a, b). This is a noteworthy trait, otherwise only found in some Choreutidae as well as Brachodes (Brachodidae), but in the latter taxa stemma 6 is separated. In Heteropsyche (Epipyropidae), the stemmata are in a stalked raspberry-like cluster, a far more extreme condition than in the other taxa listed. Therefore, the configuration of the entire stemma group can be considered a trait unique to Urodoidea + Schreckensteinioidea.

Granulose sculpturing on larval mentum (Figs 4a, c). This character is shared by Schreckensteinioidea and Urodoidea. The mentum is also sculpted in varying ways, such as being spinose or dentate, in scattered other groups or species of Lepidoptera: some Bucculatricidae (Gracillarioidea), Lyonetiidae (Yponomeutoidea), the unplaced Heliocosma and Cadmogenes, in scattered species or genera in the AlucitoideaEpermenioidea-Carposinoidea clade (sensu Heikkilä et al. 2015). The sculpturing is granulose, similar to Urodoidea and Schreckensteinioidea only in some Bucculatrix species, Lyonetia and Epermenia. Therefore, we consider this character strongly supporting the sister group relationship between Schreckensteinioidea and Urodoidea. Prolegs are medially narrowed in all known urodid and schreckensteiniid larvae, a condition not known in other Lepidoptera (Fig. 13c). This trait is a potentially unique synapomorphy uniting these groups.

All known urodids and schreckensteiniids construct a meshed cocoon, which is otherwise only present in Plutellidae, Glyphipterigidae, and occasionally with varying likeness in some macroheterocerans such as Saturniidae and Geometridae. 

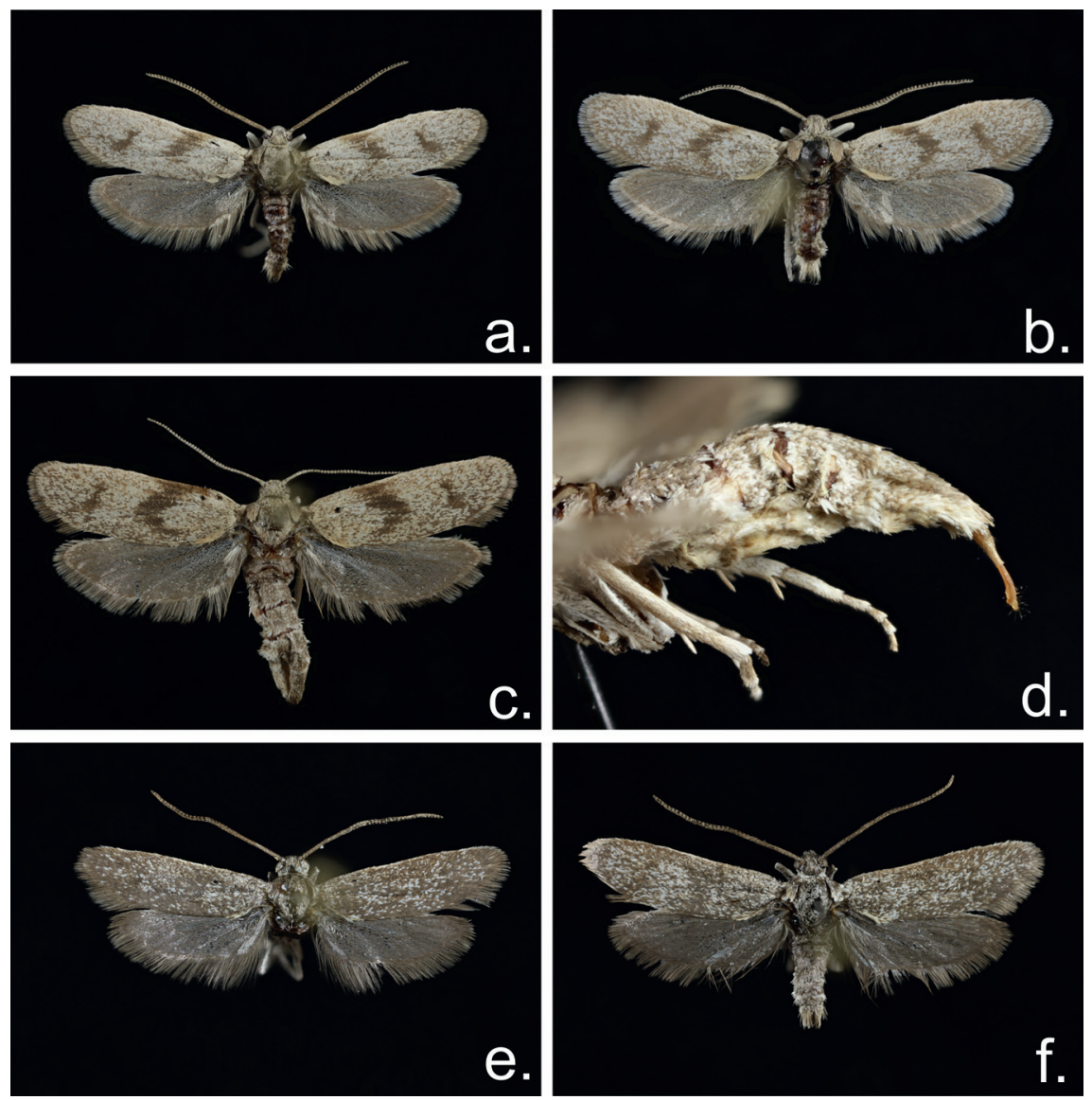

Fig. 7. a-d. Ustyurtia zygophyllivora sp. n., a. male holotype; b. male paratype; c. female paratype; d. ovipositor; e-f. Ustyurtia charynica, sp. n. male. e. holotype, f. paratype.

Larval traits that are discordant between Schreckensteinioidea and Urodoidea include the approximate condition of the primary setae in the mentum of the larva in Schreckensteinia, but not in Urodoidea. The approximate condition is rather unusual in Ditrysia, found otherwise in Galacticidae, Alucitoidea, Carposinidae, Pyraloidea, some Papilionoidea and the unplaced Cadmogenes. These setae are widely apart in Urodoidea as in most Lepidoptera.

The body is covered in microtrichiae in all known urodoid larvae. In Schreckensteinia the body is covered with heavily modified sculpturing. The shape of the sculpturing is not typical microtrichia, but rather an intermediate between lens-shape and microtrichia. Such a condition is unique in Lepidoptera. The microtrichiose body is commonly found in Yponomeutoidea, Tortricoidea, Zygaenidae, Millieriidae, Choreutidae, Carposinoidea and Thyridoidea. Due to the high level of homoplasy, we are not inclined to give much significance to this trait.

Pupal characters common to Urodoidea and Schreckensteinioidea are: 

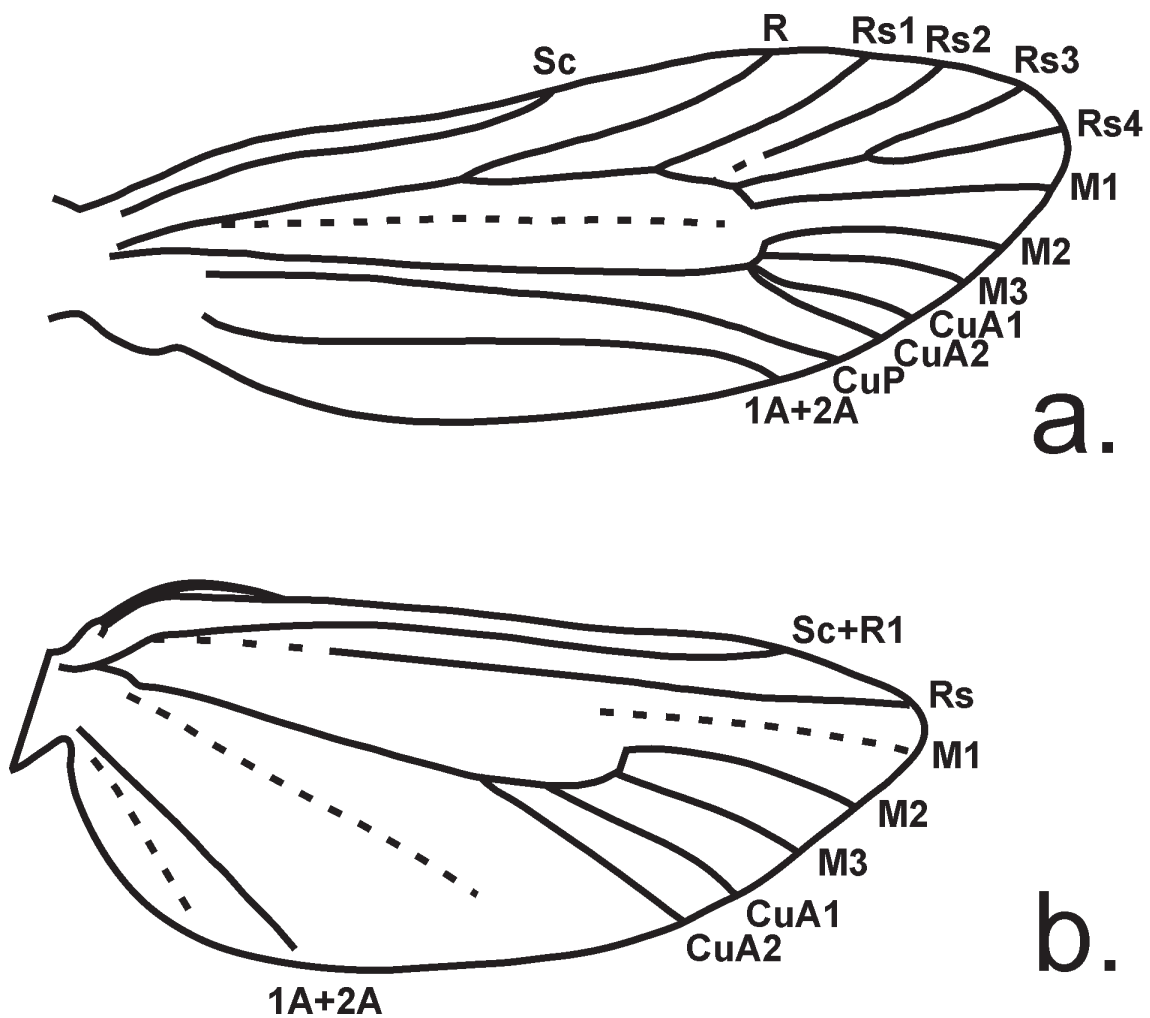

Fig. 8. Ustyurtia zygophyllivora sp. n. wing venation. a. forewing; b. hind wing.

Basic setae of pupae are distally curved in Ustyurtia, Wockia and Schreckensteinia, but not in Urodus (Figs 5, 14). Otherwise, such distally curved setae are present in Millieria (Millieriidae; superfamily status unknown) and Blastobasis (Gelechioidea: Blastobasidae).

A protuberance under the opening of the thoracic spiracle is present on the prothorax in other Urodoidea except Ustyurtia. The protuberance is not found in Schreckensteinia, but is present in all the yponomeutoid families, Heliocosma, some Epermeniidae and Immidae. It is rarely present in Cossidae and Gelechioidea among the microlepidopteran grade.

Transverse rows of spines on the dorsocaudal margin of segments of the pupal abdomen are present in all three species of Urodoidea (Fig. 5f). In Wockia a few prominent and discrete spines are present, a character also found in Schreckensteinia (Figs 14a-c). The abdominal spine rows of pupae, like the spines on abdominal segment 10, however, are a widespread trait among non-obtectomeran ditrysian Lepidoptera and thus of limited systematic value.

Adult characters indicative of a close affinity between Urodoidea and Schreckensteiniidae are scarce and only two male characters are mentioned here. The basal part of the flagellum in the male antennae in Schreckensteiniidae is expanded as in 

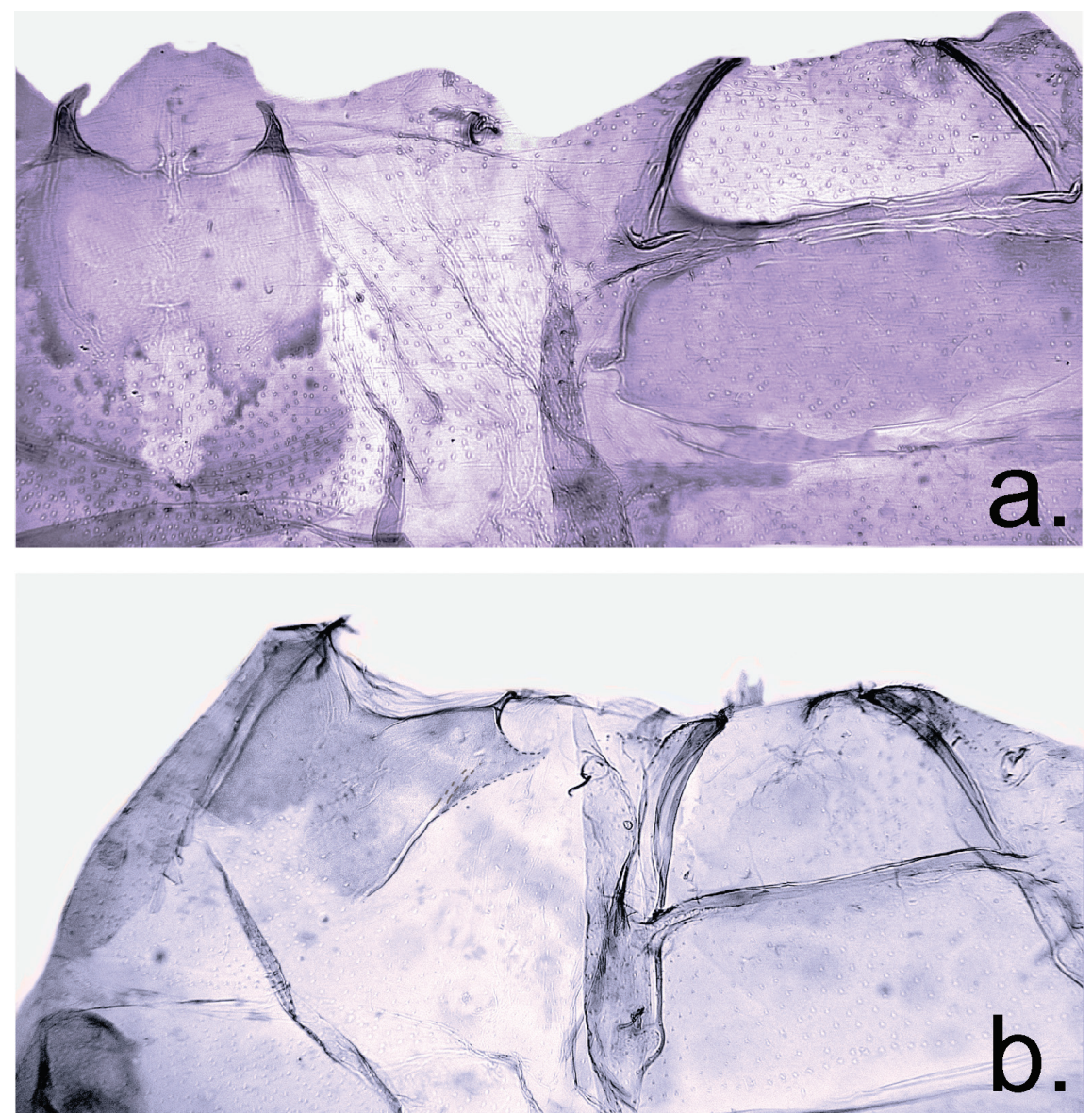

Fig. 9. Base of abdomen. a. Ustyurtia zygophyllivora sp. n., L. Kaila prep. 6069; b. Wockia asperipunctella, L. Kaila prep. 6042 .

some Urodoidea. In addition, characters of the male genitalia shared by Ustyurtia and Schreckensteinia are the long saccus and the relatively strong and narrow uncus, absent in other Urodoidea, but unlike in Ustyurtia, the genital capsule is not strongly sclerotized in Schreckensteinia. There are many differences in the adult morphology between Urodoidea and Schreckensteinioidea, generally either highly homoplastic across Ditrysia, or autapomorphies of Schreckensteinia, thus not informative.

On the presence of other 'urodoid' and 'schreckensteinioid' immature stage characters in other Ditrysia

Apart from the larval traits characterized above, most other characteristics of Urodidae tend to be quite homoplastic and often of little diagnostic value. Here we elaborate on some of them.

Larva. Pinacula of L, SD and D setae are distinct (Figs 2a, b). This trait is widespread especially in taxa having a concealed larval lifestyle. It is remarkable that Urodoidea and Schreckensteinioidea larvae live exposed, and nevertheless have conspicuous pinacula, 


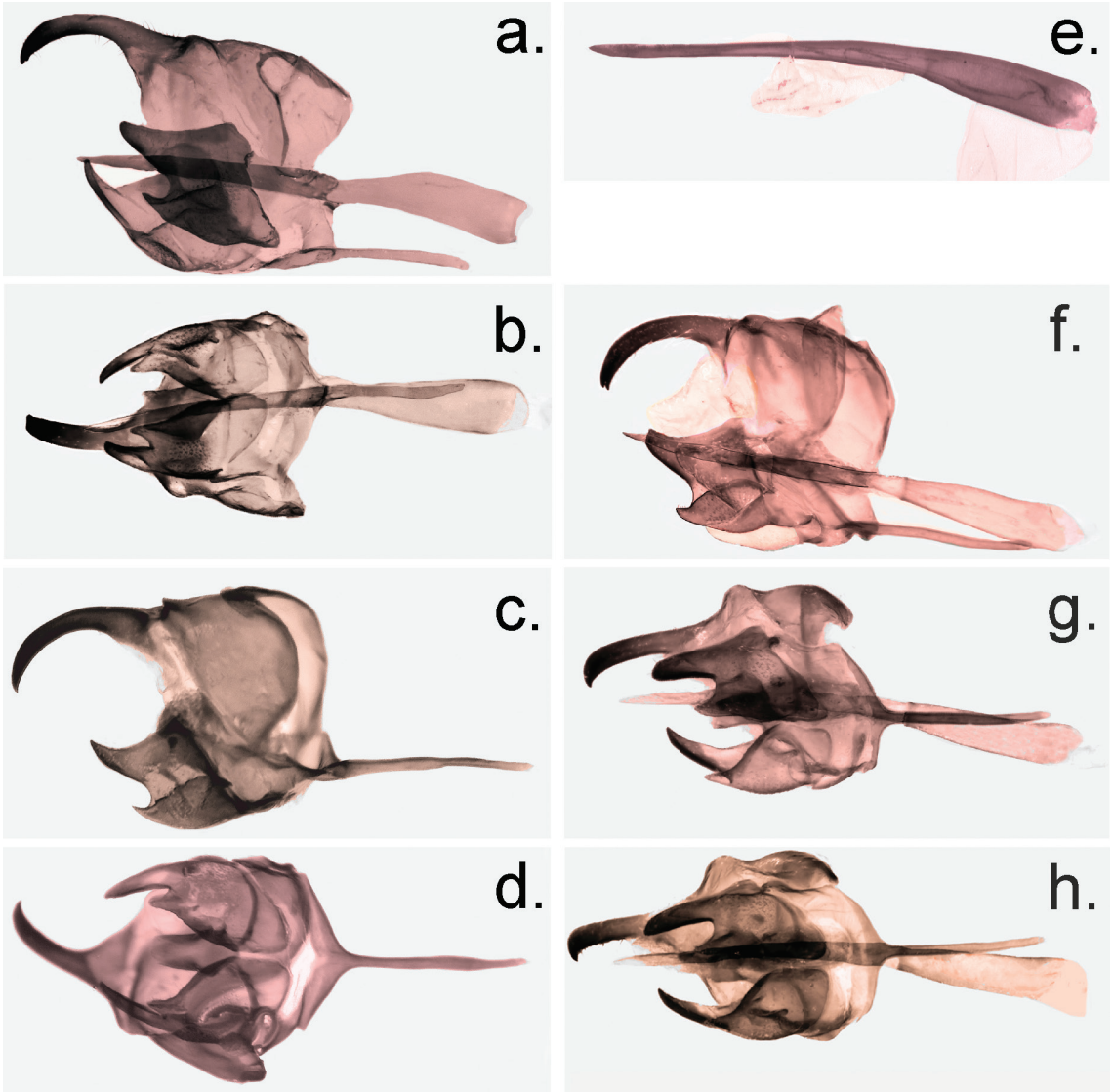

Fig. 10. Male genitalia of Ustyurtia spp., preserved in glycerol; a-e. U. zygophyllivora sp. n., paratypes, a-b. SW Kazakhstan, Onere, a-b. in ZIN, c-e. in MZH; a. and c. lateral view; b. and d. ventral view; e. phallus at same scale. $\mathbf{f}-\mathbf{h}, U$. charynica sp. n. holotype, Kazakhstan, Charyn river (Coll. Nupponen). f. lateral view; g. ventrolateral view; $\mathbf{h}$. ventral view.

also in non-aposematic species. Scaly or trichiose coverage on tarsi of thoracic legs, present in all urodoids, is also frequently found in Tineidae, Yponomeutoidea, Choreutidae, Immidae, Gelechioidea, Galacticidae, Epermenia and Pyraloidea. Setae L1 and L2 of A1-8 are approximate in Urodoidea and Schreckensteiniidae, but also in Tineidae, Gracillarioidea+Yponomeutoidea, Douglasioidea, some gelechioids, 'limacodoid families', Millieriidae, Alucitoidea, Carposinoidea and Pterophoridae. L group of larval A9 is trisetose. This is a relatively rare condition in Lepidoptera, otherwise found in some Tineoidea, some Gelechioidea, Galacticidae, Cossidae, Tortricidae, Choreutidae, Pyralidae, and the genus Ochyrotica (Pterophoridae). The base of the prolegs is elongate and forms the greater part of the proleg, and the shape of the planta is laterally bulbous (Fig. 3). This shape is found also generally in Papilionoidea and Macroheterocera (except Pyraloidea and Hesperiidae), and in microlepidopteran grade taxa in Zygaenidae. This proleg shape is typical of larvae that feed on edges of leaves (cf. Heikkilä 

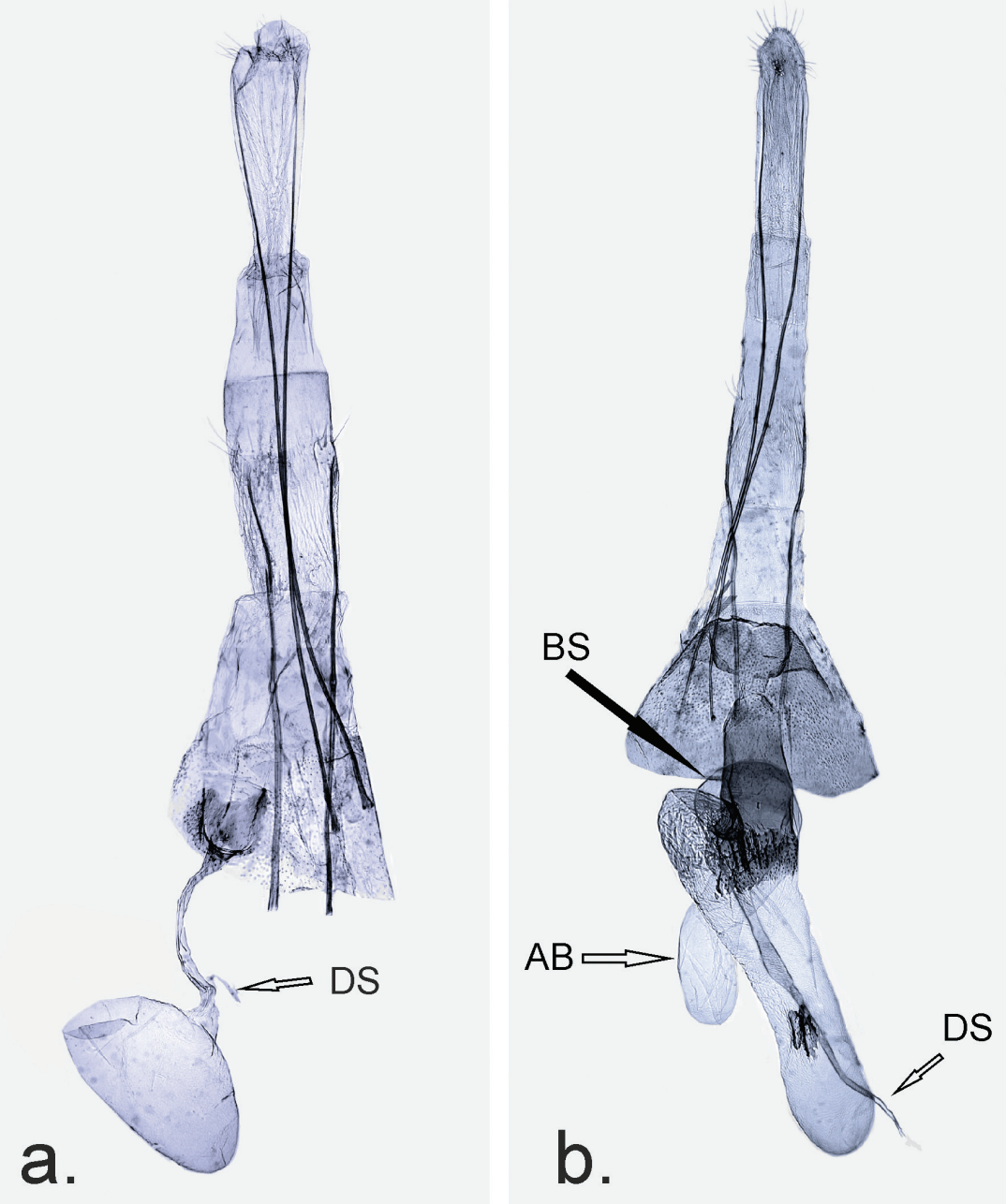

Fig. 11. Female genitalia. a. Ustyurtia zygophyllivora sp. n., L. Kaila prep. 6044; b. Wockia asperipunctella, L. Kaila prep. 6042. AB: appendix bursae; BS: bulla seminalis; DS: ductus seminalis.

et al. 2015). However, at least larvae of Schreckensteiniidae feed on the leaf surface. Crochets are arranged as a mesal penellipse in both Urodoidea and Schreckensteiniidae (Fig. 3). This arrangement, typical of most Papilionoidea and Macroheterocera except Pyraloidea and most Hesperiidae, is also found in some species in the microlepidopteran grade families Carposinidae, Pterophoridae and Alucitidae. Schreckensteiniidae possess secondary setae also on other prolegs than the anal ones. This condition is widely present in Gelechioidea and Zygaenoidea, rarely in Tortricoidea, Pterophoridae and Carposinidae, and in the unplaced Cadmogenes. Prolegs of A10 are approximate (Fig. 3b): a similar configuration is otherwise known only in Tinagma and Millieria. In the 'limacodoid' families Cyclotornidae and Epipyropidae a similar pattern is also 

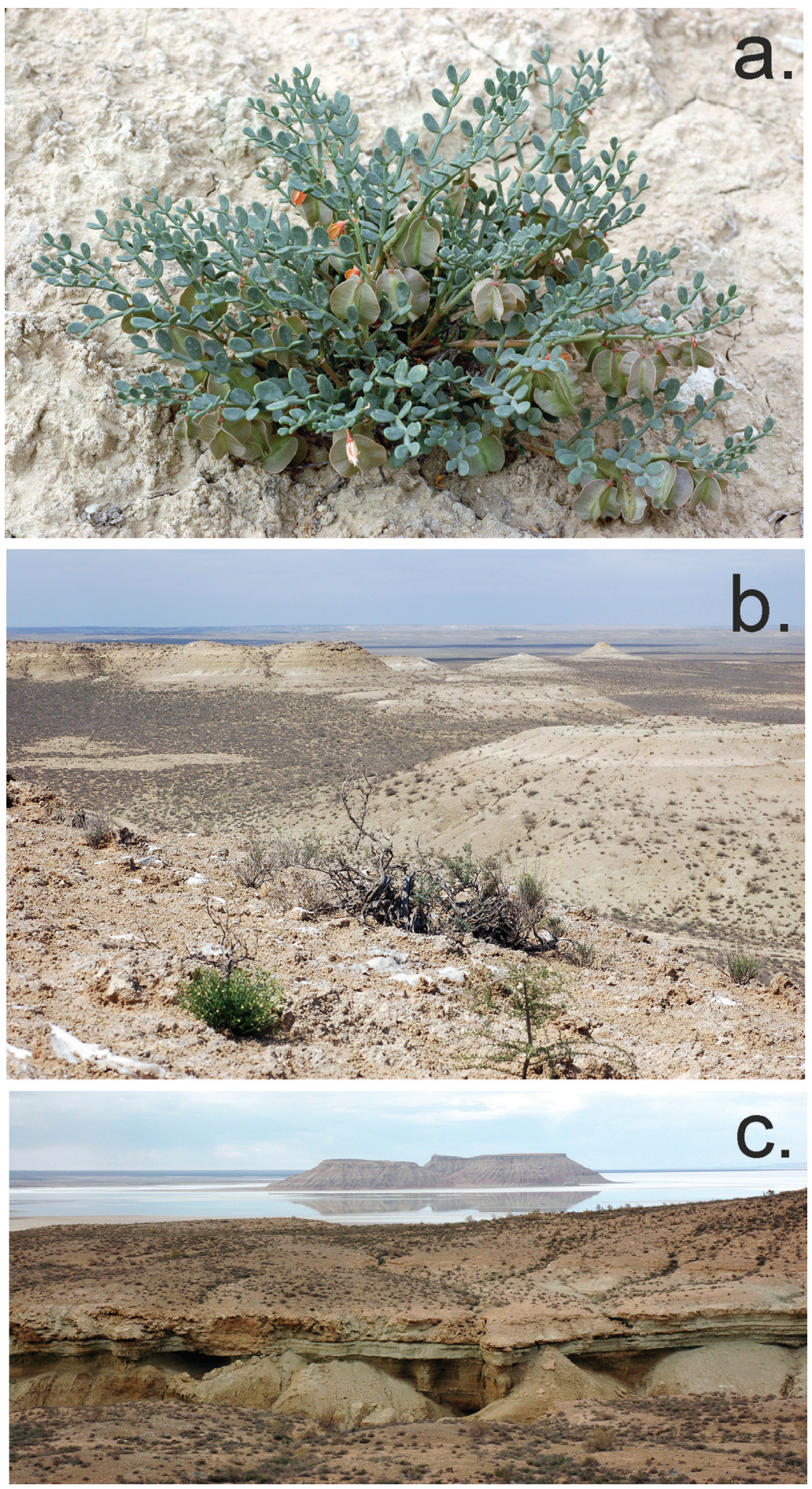

Fig. 12. Host-plant and habitat of Ustyurtia zygophyllivora sp. n., a. Zygophyllum pinnatum. b. and c. Gypsum desert of Onere along the southern shore of the salt lake, Ustyurt Nature Reserve, SW Kazakhstan. 

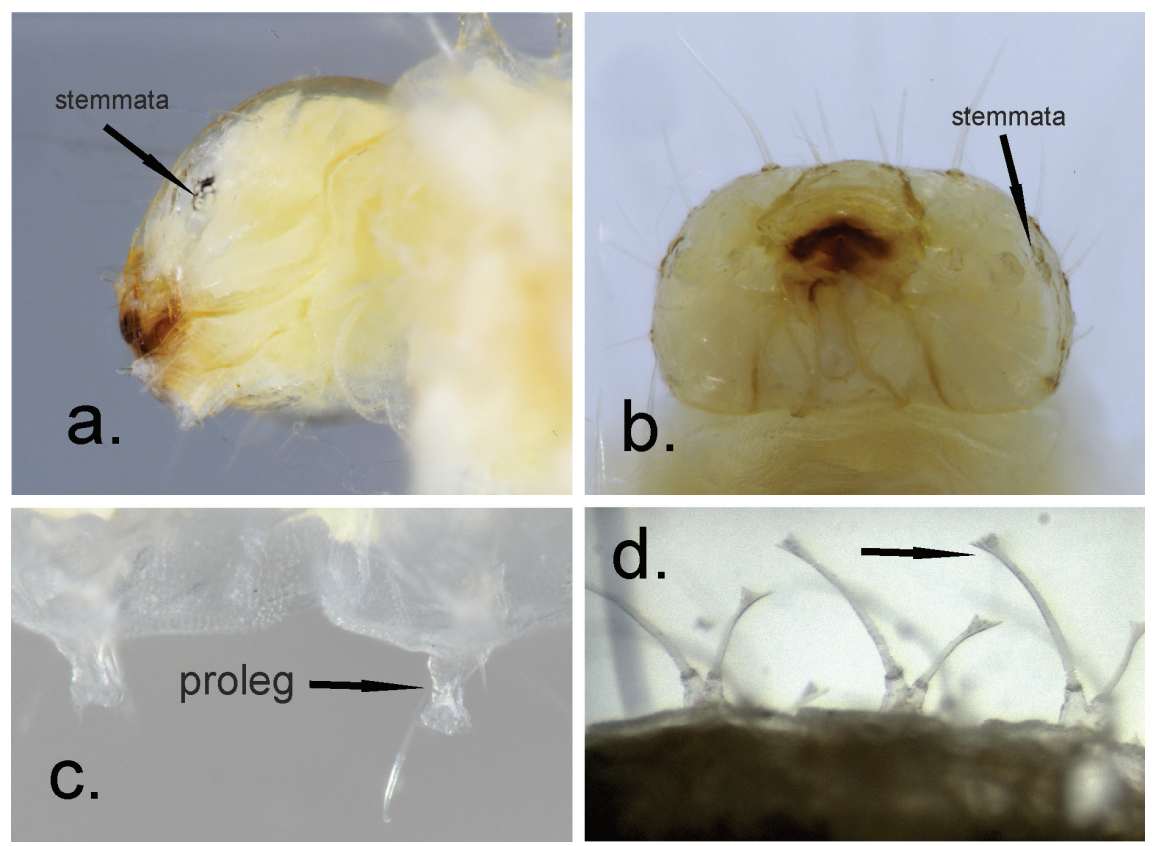

Fig. 13. Larva of Schreckensteinia festaliella. a. head, lateral view; b. head, ventral view; c. prolegs 4 and 5; d. fan-shaped apex of dorsal primary seta.

present, but their anal prolegs are on a common protuberance (cf. Epstein 1996; Heikkilä et al. 2015).

In Lepidoptera, several generally unusual immature stage characters typical of both Urodoidea and/either Schreckensteinioidea are found particularly often also in Choreutoidea and the possible monophylum (see Heikkilä et al. 2015) formed of Alucitoidea + Epermenioidea + Carposinoidea. A connection of Urodoidea + Schreckensteinioidea and these groups was not recovered in Heikkilä et al. (2015). In other studies in which Schreckensteinioidea was not included, these families were, however, often closely placed, yet almost invariably with negligible branch support (Regier et al. 2009; Cho et al. 2010; Bazinet et al. 2013).

\section{Specific characters of Schreckensteinia not recorded in other Lepidoptera}

Schreckensteinia is a highly derived taxon that displays some noteworthy characters that have been recorded in other Lepidoptera rarely or not at all, the reason for its current status as its own superfamily. These include primary setae in the larva that are distally branched and form a triangular fan-shaped apex (Fig. 13d); larval body is covered by a unique-kind of sculpturing (see above). Prolegs of A3-6 arise from an erect base making them look somewhat fused basally, a character not usually present in Lepidoptera (Fig. 13c). The pair of dorsal setae on abdominal segments A1-8 is approximate, situated on the same pinaculum in Schreckensteinioidea, unlike in nearly all other Lepidoptera, Leucoptera (Yponomeutoidea: Lyonetiidae), Crocanthes (Gelechioidea: 

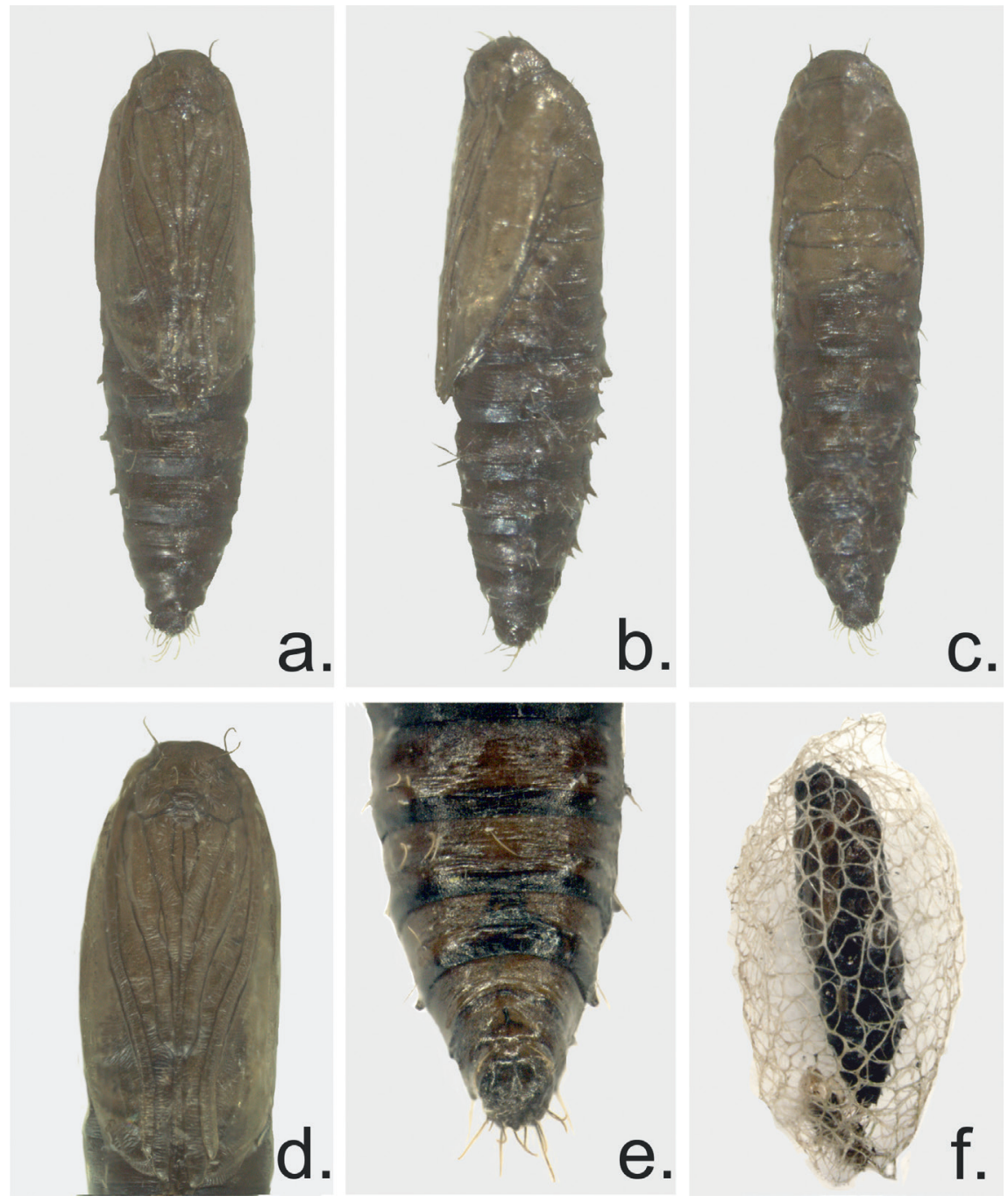

Fig. 14. Pupa of Schreckensteinia festaliella. a. Pupa in ventral view; b. lateral view; c. dorsal view; d. head and thorax; e. abdomen in ventral view; $\mathbf{f}$. cocoon with uneclosed pupa.

Lecithoceridae) and Lacturidae (Zygaenoidea) as exceptions. Setae D1, D2 and SD1 are placed on a common pinaculum on A9, which is unique in Lepidoptera.

Adult characters rarely found in other Lepidoptera include the stiff spines on the dorsal side of the tibia and the female frenulum consisting only of one bristle (Dugdale et al. 1998).

\section{Conclusions}

The newly described family Ustyurtiidae shares most traits specific to Urodidae (Urodoidea), yet differs in some significant ways from other constituent genera. This, 
along with its position based on molecular analyses, supports its status as a distinct family of Urodoidea and the sister group relationship between Ustyurtiidae and Urodidae. The only molecular analyses that include both Schreckensteinioidea and Urodoidea give a signal, yet weak, that these superfamilies might be closely related. This view is supported by a number of shared immature characters. However, we deem the current evidence not sufficient to unite these superfamilies, pending on better coverage of immature stages of more urodoid genera or stronger molecular support.

\section{Formal taxonomy and descriptions}

\section{Ustyurtia Kaila, Heikkilä \& Nupponen, gen. n.}

\section{ZooBank: http://zoobank.org/06F4B5BC-F810-4F6F-BFBE-B48C76A015E5}

\section{Type species: Ustyurtia zygophyllivora Kaila, Heikkilä \& Nupponen, sp. n.}

Diagnosis. Ustyurtia is distinguished from all other urodid genera by the stalked Rs3 and Rs4 and the absence of an accessory cell in the forewing. Male genitalia are distinctive from all other urodid genera by the immobile, basally fused valvae, the long, curved, strongly sclerotized uncus, and the vinculum that is prolonged to form a long and slender saccus. The structure of the cocoon is similarly meshed as in other Urodidae. Yet unlike in others, it is densely filled with silk that forms a stiff layer, and has longitudinal ribs that cephalically separate the cocoon into several lobes during adult eclosion. In addition, the male is distinguished from Urodus Herrich-Schäffer, 1854, Wockia Heinemann, 1870 and Incawockia Heppner, 2010 by the absence of a costal hair-pencil in the hind wing. Spiladarcha Meyrick, 1913 and Anomalomeuta Sohn, 2013 have small black dots of raised scales along the upper side of the forewing veins, which are absent from Ustyurtia. From Geoesthia Sohn, 2014, Anomalomeuta, Incawockia, Spiladarcha, and Wockia it also differs by the absence of a patch of raised scales on the forewing median line. From Anchimacheta Walsingham, 1914 and Glaucotunica Sohn, 2014 Ustyurtia differs by the male genitalia, the absence of a bilobed uncus in the latter being one of the most conspicuous differences.

All other recognized genera of Urodoidea belong in the family Urodidae.

Description. Description of Ustyurtia is referred to the description of the type species, U. zygophyllivora below.

Etymology. The generic name alludes to the geographical origin of the type species, the Ustyurt plateau in southwestern Kazakhstan.

\section{Ustyurtiidae Kaila, Heikkilä \& Nupponen fam. n.}

Type genus: Ustyurtia Kaila, Heikkilä \& Nupponen gen. n.

Diagnosis. Equivalent to the diagnosis of the genus Ustyurtia above.

ZooBank: http://zoobank.org/A83377E8-D892-4186-B0A8-FABEEA61D6FB 
Ustyurtia zygophyllivora Kaila, Heikkilä \& Nupponen sp. n. (Figs 2-3; 4a, b; 5-7a-d; 8; 9a; 10a-e; 11a; 12).

\section{ZooBank: http://zoobank.org/A4F80EAD-03B5-47A1-95C6-CA5800708EF3}

Diagnosis. The adult of $U$. zygophyllivora is very unlike other members of Urodoidea, in being rather narrow-winged and stout-bodied, and the female with a relatively large abdomen and a conspicuous ovipositor. Rather, its appearance resembles that of species of Brachodidae. The forewing is grey, with a pattern of a brownish grey outwardly angled fascia at the basal $1 / 3$ of the wing, and a fused pair of small spots of the same colour at distal $3 / 4$ of wing. The male differs from other urodoids in having strongly capsulated genitalia with the valvae immobile and without strong setae or spines. The female genitalia lack a large dilation at base of the ductus seminalis, typical of most representatives of other urodoid genera. Separation of $U$. zygophyllivora and $U$. charynica is explained in the diagnosis of $U$. charynica. The larva possesses the family synapomorphies of Urodidae listed above, and elaborated below. In outer appearance it is colourful with black ground colour and large, black pinacula that are surrounded with circles, and laterally with a broad, orange longitudinal line. The cocoon is shaped as an upturned boat, mesh-structured, densely filled with silk that forms a stiff layer, and with longitudinal ribs that cephalically separate the cocoon into lobes during adult eclosion.

\section{Description.}

Larva (Figs 2; 3a, b; 4a, b)

Length $16 \mathrm{~mm}$ (last instar, alcohol preserved, somewhat relaxed in $\mathrm{KOH}$ ). Appearance strongly aposematic with bright colouration (Fig. 2): ground colour black, large and stiff setae on very large erected pinacula that are centrally black and surrounded by a white circle. Laterally broad, orange longitudinal line, colouring dorsally formed of narrow black dorsal stripe, black-and-white pinacula and pale grey spots on each segment. Thoracic legs black, prolegs white with black setae. Body setae large and stout. Prothoracic and anal plates not sclerotized. Cuticulum of thoracic legs scaly. Prolegs on a conspicuous, laterally inflated swelling, distally elongate and medially narrowed (Fig. 3); crochets in mesoseries. Prolegs on A10 closely set, crochets in a curved row, homoideus (Fig. 3b). Anal comb absent.

Head (Figs 4a, b) semiprognathous, retractile, reddish brown with dark brown markings along epicranial and adfrontal suture, and elongate dark brown stripes near MD setae. All stemmata present, close to each other. Primary setae stout, no secondary setae present. Head smooth without depressions in frons; labrum anteriorly with shallow notch; spinneret tubular, tapered toward apex, without distal lobes; fusuliger extended near apex of spinneret; labial palpi dorsolaterad of spinneret. Mentum swollen, granulose. Primary setae of mentum widely apart from each other. No secondary setae present on mentum.

Thorax. All setae large and stiff. Claws nearly straight, with black basal loop; setae of thoracic legs not modified. 
Body chaetotaxy (Fig. 2). All setae large and stiff.

Prothorax: D1 longer than D2, on same pinaculum. SD group bisetose, setae on common pinaculum. L group trisetose, L2 dorsad of L1 and L3, L1 and L2 on same pinaculum; SV group bisetose, setae on same pinaculum; V setae posterior to prolegs.

Meso-and metathorax: D1+ D2 and SD1 + SD2 on common pinacula; D1 of prothorax significantly shorter than D2. L1, L2 and L3 each on separate pinacula. SV group unisetose. V on base of prothoracic leg. SV1, VI and two MV setae on swollen, posteriorly sclerotized coxae on all thoracic legs.

Abdomen: spiracles very small on segments $1-8$. D1 anteromesially to D2 on A17, on the same anteroposterior line on A8, anterolateral to D2 on A9. SD2 minute, anterodorsal of the spiracle on segment 1 and anterior to the spiracle on segments 2-8. L1 and L2 on common pinaculum. L3 ventroposterior to L1 and L2 on segments $1-7$, ventroanterior to them on segment 8 . One SV seta on segments 1, 2 and 7-9, SV group trisetose on segments 3-6. SV1 positioned almost as high laterally as L3 on segment 8 . Ventral and anal prolegs very long and narrow, medially constricted, on large basal swellings, 15-20 uniordinal and uniserial crochets in a mesoseries. Prolegs not arising on integumental swelling; subventral and ventral setae on laterally conspicuously enlarged, basal part (planta) of proleg on segments 3-6. V group unisetose on A1-2 and 7-9, absent on A3-6. A9: D1 and D2 of equal length, D1 ventrad of D2, D1 separate from SD1, D2 setae separate from each other, L group trisetose, SV group bisetose. No secondary setae on prolegs.

\section{Pupa (Fig. 5)}

Length of uneclosed pupa 8-10 mm. Unicolourous chocolate brown, well sclerotized. Body parts lightly fused to each other and body, becoming free in eclosion. Integument somewhat sculpted and sparsely covered with short setae except on A7-10. A1-7 dorsally densely covered by light brown stiff hairs. Primary setae present, some of them hook-shaped.

Head and thorax. Short, pointed forward directed protuberance on cephalic part of clypeus. Visible epicranial and frontoclypeal sulci present. Mandible distinguishable by externally visible sulcus. Labial palpus present as vestigial. Haustellum as long as prothoracic femur, laterally somewhat extended, conical. Antenna as long as mesothoracic leg. Maxillary palpus very narrow. Flagellae entirely separate. Prothoracic coxa concealed, femur visible. Mesothoracic coxa visible, distal part of mesothoracic legs meeting each other. Opening of thoracic spiracle visible, in narrow pit, on T2. Mesothorax dorsally sculpted, with irregular transverse fold formed. Metathorax dorsally with prominent longitudinal furrows.

Abdomen. Spiracles not erected. Intersegments 3-7 movable. Row of spines dorsally on segments 4-7 near caudal margin; less pronounced spines near dorsocephalic margin on segments $6-8$. Scars of prolegs not present. Abdomen without longitudinal ridges. A8 and A9, as well as A9 and A10 separated by discernible sulcus. Cremaster not developed; A10 with row of hook-shaped setae. 


\section{Cocoon (Fig. 2c)}

Shaped as an upturned boat; mesh-structured, densely filled with silk that forms a stiff layer; with longitudinal ribs that cephalically separate the cocoon into several lobes during adult eclosion.

\section{Adult (Figs 6-11)}

Head. Scale vestiture of head consisting of mixed white-pale yellow and brown scales; frons, vertex and occiput with appressed lamellate scales; scales on vertex longer and narrower than those on the frons. Haustellum rudimentary, short, unscaled. Maxillary palpus minute, 1-segmented, unscaled. Labial palpus short, 3-segmented, scaled. Pilifers present, with gold-coloured setae extending to cover base of haustellum. Chaetosemata absent. Ocelli absent. Few scales between compound eye and antenna. Antenna nearly as long as wings; scape with white scales; no pecten; antennal flagellum wider basally and laterally flattened in male, filiform in female; on dorsal side of each flagellomere irregular rows of pale yellow scales and scattered iridescent violet scales; on ventral side of flagellomeres only one row of yellow scales; no long sensilla.

Thorax. Forewing length 7-8 mm; dorsal side with white scales with yellow shimmer and scattered brown scales; light brown scales more abundant at base of wing; light brown scales form a fascia reaching diagonally from the basal $1 / 3$ of the costa outward toward the tip of the wing then at approximately mid wing turning diagonally inward (medially) almost reaching the inner margin; a patch of light brown scales at approximately mid wing at distal $1 / 3$ of the wing; base of dorsal margin with patch of yellowish white scales; fringes yellowish white and very light brown; ventral side of forewings with off-white scales. Hindwing with white to very light brown scales on dorsal side, scales on ventral side white, fringe very light brown; no costal hair-pencil. Male frenulum one compound seta. Female with three acanthi. Forewing venation (Fig. 8a; 3 exx. examined): Granulose reinforcement ('pterostigma') absent or marginally present in middle of forewing costa; Sc extended to middle of forewing length, in male with retinaculum arising as lobe near base; chorda absent; R-Rs3 on costa or costal side of apex, Rs3 stalked with Rs4, directed to apex of forewing; $\mathrm{M}_{1+2}$ present as fold; distal margin of termen weakly expressed; three $\mathrm{M}$ veins and two $\mathrm{CuA}$ veins present, from distal margin of cell to termen, $\mathrm{M}_{3}, \mathrm{CuA}_{1}$ and $\mathrm{CuA}_{2}$ rather approximate; $\mathrm{CuP}$ and $1 \mathrm{~A}+2 \mathrm{~A}$ entirely present.

Hind wing venation (Fig. $8 \mathrm{~b}$ ): $\mathrm{Sc}+\mathrm{R}$ extended to $4 / 5$ wing length; Rs free, from base to $2 / 3$ wing length present as fold, distally fully developed vein extended to wing margin slightly costal of apex; $M_{1}$ basally indistinct, bent, arising from dorsal margin of cell; $\mathrm{M}_{2}, \mathrm{M}_{3}, \mathrm{CuA}_{1}$ and $\mathrm{CuA}_{2}$ separate; $\mathrm{CuP}$ almost indiscernible, ghost-like, yet developed as vein; $1 \mathrm{~A}+2 \mathrm{~A}$ well developed, almost reaching anal margin; $3 \mathrm{~A}$ vestigial.

Tegula with light brown scales, yellow shimmer. Meso- and metanotum with offwhite and light brown scales, yellow shimmer. Procoxa and femur with white and diffuse light brown scales, tibia and tarsus with light brown scales and white scales at apex of each segment. Meso- and metathoracic legs with white scales. Epiphysis present. Tibial spur formula 0-2-4. Tarsi with spines on ventral side. Hind tibia without long hair-like scales. 
Abdomen. Intermixed off-white and light brown scales, yellow-golden shimmer. Male with long narrow scales at tip of abdomen. Apodemes of sternum II lacking venulae; sternum II without anterolateral projections of the "tortricid type" (Fig. 9).

Male genitalia (Figs 10a-e). Genital capsule heavily sclerotized. Costal process absent. Uncus entirely fused, curved, with shallow distal notch, as long as tegumen, from which it is entirely articulated, in lateral view (Figs 10a, c); rising slightly from the tegumen at a shallow angle. Anterior margin of tegumen concave. Gnathos reduced. Anellus not present; juxta broadly surrounding phallus ventrolaterally. Valva immobile, at anterior end basally fused, with articulation with vinculum, costa distally tapered. Vinculum tapered into narrow and sclerotized saccus, length of sacculus equal to length of tegumen. Phallus not ankylosed; needle-shaped, nearly as long as vinculum + tegumen + uncus, without caecum; broadest basally, gradually tapered into pointed apex; without cornuti.

Female genitalia (Fig. 11a). Ovipositor extensile, anterior and posterior apophyses long, posterior apophyses ca. $1 \frac{1}{1} 2$ length of anterior apophyses. Ostium bursae round, lightly sclerotized; ductus bursae membranous, length about $1 / 4$ length of posterior apophysis, widened at junction with corpus bursae. Ductus seminalis at junction of ductus bursae and corpus bursae. Corpus bursae elliptical, width equal to length of ductus bursae. Signum absent.

Distribution. SW Kazakhstan. The species is known only from three sites in a restricted area along shores of a large salt lake located in southern Ustyurt plateau.

Biology. The species inhabits gypsum deserts by shores of a salt lake (Fig. 12). Caterpillars appear in early spring, beginning of April in average year, and pupate no later than early May. The larva feeds on Zygophyllum spp. (Zygophyllaceae), preferring flowers at least in early instars. Zygophyllum turcomanicum Fischer ex Kar. and Z. pinnatum Cham. were verified as hosts in the field. Larvae are most active during the hottest time of the day in the early afternoon; they stay exposed all the time. Pupation takes place in a cream-coloured cocoon attached to a stem or branch of the host. Adult males fly at daylight, from early afternoon to late evening. The moth flies rapidly rather short distances (appr. $10 \mathrm{~m}$ ) close to the soil surface. Its behavior resembles that of a pyralid moth Ratasa alienalis (Eversmann, 1844). Wings of the female are full-sized, but due to the large abdomen the female is probably capable of flying only very short distances, if at all.

DNA barcode. The $658 \mathrm{bp}$ long fragment of the mitochondrial DNA barcode region (COI) is highly unique and over $7 \%$ different from the barcode of any other species presently deposited in BOLD except for the closely related $U$. charynica. The Kimura 2-parameter divergence between the two Ustyurtia species is $1.69 \%$, indicating close relationship between them.

Etymology. The species name refers to its larval host plant, Zygophyllum spp.

Remarks. During 2013 and 2014, larvae of the new species were searched for in numerous localities in western Kazakhstan by the authors P. Gorbunov and K. Nupponen, northwards up to the $48^{\circ} \mathrm{N}$. The host plants, Zygophyllum spp. are locally abundant in 
chalk hills by the River Emba, as well as in the Chalkar range north from the Aral Sea. However, there were no signs of occurrence of $U$. zygophyllivora in those regions, although many habitats were superficially similar to those in the southern Ustyurt range. Thus, the distribution range of $U$. zygophyllivora seems to cover only a restricted area in the southern corner of the Ustyurt range. The Ustyurt plateau has repeatedly been geographically isolated for long periods during various transgressions of the Caspian Sea (Shovkoon 2010), which may explain such a limited distribution.

Material examined:

Type material. Holotype m, SW Kazakhstan, 4257’23”N 54²1'21”'E, 115 m a.s.l., Ustyurt Nature Reserve, Kendyrli, larva found 11.iv.2013 on Zygophyllum turcomanicum/Z. pinnatum, imago emerged 4.-11.v.2013, K. Nupponen leg., In research collection of K. \& T. Nupponen, to be deposited in MZH. Paratypes (total $62 \mathrm{~m} 31 \mathrm{f}$ ): the same collecting information as for the holotype, $10 \mathrm{~m} 7 \mathrm{f}, \mathrm{K}$. Nupponen leg., L. Kaila wing preparation 6038, K. Nupponen m gen. prep. 4/25. xii.2015 (Coll. Nupponen \& MZH); same locality, 19.v.2011, 3 m, K. Nupponen leg.

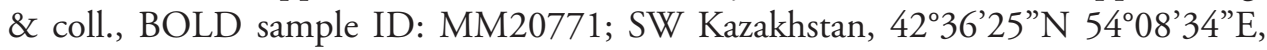
0-47 m a.s.l., Ustyurt Nature Reserve, Onere, larvae found 12.iv.2013 on Zygophyllum turcomanicum/Z. pinnatum, imagoes emerged 3.-7.v.2013, 43 m 24 f, K. Nupponen leg., L. Kaila wing preparation 6039, L. Kaila f gen. prep. 6044, K. Nupponen m gen. prep. 1/25.xii.2015, f gen. prep. 2/7.iii.2015 (Coll. Nupponen \& MZH); same locality, 16.v.2011, 2 m, 17.v.2011, 1 m, K. Nupponen leg. \& coll.; same locality, larvae found 13.v.2009 on Zygophyllum turcomanicum/Z. pinnatum, imagoes emerged 28.v.2009,

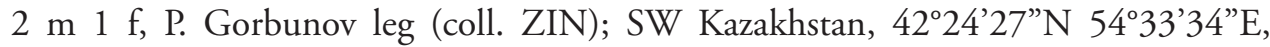
80 m a.s.l., Ustyurt Nature Reserve, Mametkazgan, 22.v.2011, 1 m, K. Nupponen leg. \& coll.

Additional material. 4 larvae, 2 pupae, 25 pupae attached to cocoons with adult

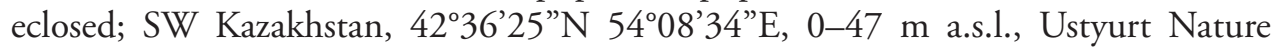
Reserve, Onere, larvae found 12.iv.2013 on Zygophyllum turcomanicum/Z. pinnatum $(\mathrm{MZH})$.

\section{Ustyurtia charynica sp. n. Kaila, Heikkilä \& Nupponen sp. n. (Figs 7e, f; 10f-h).}

ZooBank: http://zoobank.org/B46500A7-4F08-4A6B-B0CB-43C5AB57BE2F

Diagnosis. Only the male of Ustyurtia charynica is known. It is distinguished from the male of $U$. zygophyllivora by the wing pattern, male genitalia and DNA barcodes. The forewings of $U$. charynica are almost unicolourous dark grey with paler grey peppering with a pair of dark grey spots at $3 / 4$ wing length barely visible; these markings as well as a dark, outwards angled fascia at $1 / 3$ wing length, are distinctive in the considerably paler $U$. zygophyllivora. The base of the uncus is narrower in $U$. charynica than in U. zygophyllivora. The uncus is also somewhat dorsally directed in U. zygophyllivora, 
unlike in $U$. charynica. In dorsal aspect the tegumen is narrower in $U$. charynica than in U. zygophyllivora. The apex of the ventral margin of the valva is blunter and less tapered in $U$. charynica than in U. zygophyllivora.

Description. Larva and pupa unknown.

Adult (Figs 7e, f; 10f-h)

Head. Scale vestiture consists of mixed white and brown scales; frons, vertex and occiput with appressed lamellate scales; scales on vertex longer and narrower than those on the frons. Haustellum rudimentary, short, unscaled. Maxillary palpus minute, 1-segmented, unscaled. Labial palpus short, 3-segmented, scaled, no distinct scale tufts. Pilifer present, with gold-coloured setae extending to cover base of haustellum. Chaetosema absent. Ocellus absent. Few scales between compound eye and antenna. Length of antenna almost equal to wing length; scape with mostly brown scales, a few scattered white scales; no pecten; male antennal flagellum filiform, laterally slightly flattened, wider basally; on dorsal side of each flagellomere irregular rows of brown scales and scattered iridescent yellow scales; on ventral side of flagellomeres only one row of yellow scales; no long sensilla.

Thorax. Forewing length $6-7 \mathrm{~mm}(\mathrm{n}=3$ males); dorsal side of wings with intermixed white and brown scales; a faint irregular patch of slightly darker brown scales at distal apex of discal cell; base of dorsal margin with patch of white scales; fringe light brown; ventral side of forewings with light brown and scattered white scales, white scales on retinaculum. Forewing venation: Sc extended to middle of forewing length, in male with retinaculum arising as lobe near base; chorda absent; R-Rs3 on costa or costal side of apex, Rs4 stalked with Rs3, directed to apex of forewing; three $M$ veins and two $\mathrm{CuA}$ veins present, from distal margin of cell to termen, $\mathrm{M}_{3}, \mathrm{Cu} \mathrm{A}_{1}$ and $\mathrm{CuA}_{2}$ rather approximate; $\mathrm{CuP}$ and $1 \mathrm{~A}+2 \mathrm{~A}$ entirely present.

Hindwing unicolourous light brown on dorsal and ventral side, fringe light brown; no costal hair-pencil. Male frenulum one compound seta. $\mathrm{Sc}+\mathrm{R}$ extended to $3 / 4$ wing length; $\mathrm{R}_{\mathrm{S}}$ free; $\mathrm{M}_{1}, \mathrm{M}_{2}, \mathrm{M}_{3}, \mathrm{CuA}_{1}$ and $\mathrm{CuA}_{2}$ separate; $\mathrm{CuP}$ faint but present. Wing slides not made due to the scarcity of material; therefore further details not deciphered with certainty.

Tegula with brown and white scales, mostly white at apex. Meso- and metanotum with intermixed light brown and white scales. Procoxa and femur with white and scattered light brown scales. Epiphysis present. Tibia and tarsus with white and light brown scales, white scale at distal margin of each segment. Meso- and metathoracic legs with white scales, scattered with very light brown scales. Tibial spur formula $0-2-4$. Tarsi with spines on ventral side. Hind tibia without long hair-like scales.

Abdomen. Tergum with light brown scales, some off-white scales at tip of abdomen. Male with long narrow scales with yellow-golden shimmer at tip of abdomen.

Male genitalia (Figs 10f-h) Genital capsule heavily sclerotized. Costal process absent. Uncus entirely fused, as long as tegumen, curved, in lateral view at level with tegumen, apex of uncus approaching apices of valvae, from which it is entirely articulated, tip 
shallowly notched. Anterior margin of tegumen concave. Gnathos reduced. Anellus absent; juxta broadly surrounding phallus ventrolaterally. Valva immobile, at anterior end basally fused, with articulation with vinculum, costa distally tapered and articulated from rest of valva. Vinculum tapered into narrow and sclerotized saccus, length of which equal to length of tegumen. Phallus not ankylosed; needle-shaped, nearly as long as vinculum + tegumen + uncus, without caecum; broadest basally, gradually tapered into pointed apex; without cornuti.

Distribution. SE Kazakhstan, Charyn.

Biology. The specimens were swept in the forenoon at a rocky steppe slope with sparse vegetation. Zygophyllum sp. was present at the collecting site.

DNA barcode. The $658 \mathrm{bp}$ long fragment of the mitochondrial DNA barcode region (COI) is highly unique and with an over $7 \%$ difference to the barcode of any other species presently deposited in BOLD except for the closely related U. zygophyllivora. For differences between the two new species, see under U. zygophyllivora above.

Etymology. The species name refers to its geographical origin, the Charyn canyon in southeastern Kazakhstan.

Material examined:

Type material. Holotype m: Kazakhstan, 4314’36”N 78²'48”E, Charyn River, 1220 m a.s.l., 2.vi.2017, K. Nupponen \& R. Haverinen leg. (BOLD sample ID for the sequenced specimen: MM26056). Holotype in research collection of K. \& T. Nupponen, to be deposited in MZH. Paratypes: $3 \mathrm{~m}$ with the collecting data as in the holotype (MZH, Coll. Nupponen).

\section{Acknowledgements}

We express our gratitude to Elvira Rättel and Pekka Vilkamaa for their help in photographing specimens. David Adamski and Jae-Cheon Sohn helped in accessing literature and giving insight on the morphology on Urodidae. Staff of Ustyurt Nature Reserve permitted access to the Reserve and supported the field work. Risto Haverinen and Stanislav Korb organized the expedition to the Charyn range and helped in the field work. Alexander Ivanov, Elena Nupponen, Timo Nupponen and Vladimir Olschwang supported the expedition to SW Kazakhstan in various ways. Jadranka Rota and an anonymous reviewer are thanked for their help in improving an earlier version of the manuscript.

\section{References}

Bazinet, A.L., Cummings, M.P., Mitter, K.T. \& Mitter, C.W. (2013) Can RNA-Seq resolve the rapid radiation of advanced moths and butterflies (Hexapoda: Lepidoptera: Apoditrysia)? An exploratory study. PLoS ONE 8: e82615. doi:10.1371/journal.pone.0082615.

Cho, S., Zwick, A., Regier, J.C., Mitter, C., Cummings, M.P., Yao, J., Du, Z., Zhao, H., Kawahara, A.Y., Weller, S., Davis, D.R., Baixeras, J., Brown, J.W. \& Parr, C. (2011) Can deliberately incomplete 
gene sample augmentation improve a phylogeny estimate for the advanced moths and butterflies (Hexapoda: Lepidoptera)? Systematic Biology 60 (6): 782-796. doi: 10.1093/sysbio/syr079.

Clarke, J.F.G. (1965) Catalogue of the type specimens of Microlepidoptera in the British Museum (Natural History) described by Edward Meyrick. (Vol. 5). British Museum (Natural History), London, United Kingdom: 581 pp.

deWaard, J.R., Ivanova, N.V., Hajibabaei, M. \& Hebert, P.D.N. (2008) Assembling DNA barcodes: analytical protocols. In: Christofre, M.C. (ed.) Methods in molecular biology: environmental genetics. Humana Press, Totowa, NJ, USA: pp. 275-293.

Dugdale, J.S., Kristensen, N.P., Robinson, G.S. \& Scoble, M.J. (1998) The smaller Microlepidopteragrade superfamilies. In: Kristensen, N.P. (ed.) Handbook of Zoology IV: Lepidoptera, moths and butterflies. Vol.1: Evolution, systematics and biogeography. Walter de Gruyter, Berlin, New York: pp. 217-232.

Edwards, E.D., Gentili, P., Horak, M., Kristensen, N.P. \& Nielsen, E.S. (1998) The cossoid/sesioid assemblage. In: Kristensen. N.P. (ed.) Handbook of Zoology IV: Lepidoptera, moths and butterflies. Vol.1 Evolution, systematics and biogeography. Handbuch der Zoologie/Handbook of Zoology 35. Walter de Gruyter, Berlin, New York, pp. 181-197.

Epstein, M. (1996) Revision and phylogeny of the limacodid-group families, with evolutionary studies on slug caterpillars (Lepidoptera: Zygaenoidea). Smithsonian Contributions to Zoology 582: 1-102.

Friese, G. (1966) Ergebnisse der Albanien-Expedition 1961 des Deutschen Entomologischen Institutes 52. Beitrag Lepidoptera: Plutellidae. Beiträge zur Entomologie 16 (3-4): 447-459. doi: 10.21248/ contrib.entomol.16.3-4.447-459.

Heikkilä, M., Mutanen, M., Wahlberg, N., Sihvonen, P. \& Kaila, L. (2015) Elusive ditrysian phylogeny: An account of combining systematized morphology with molecular data (Lepidoptera). BMC Evolutionary Biology 15 (1). doi: 10.1186/s12862-015-0520-0.

Hinton, H.E. (1946) On the homology and nomenclature of the setae of lepidopterous larvae, with some notes on the phylogeny of the Lepidoptera. Transactions of the Royal Entomological Society of London 97: $1-37$.

Kaila, L., Mutanen, M. \& Nyman, T. (2011) Phylogeny of the megadiverse Gelechioidea (Lepidoptera): adaptations and determinants of success. Molecular Phylogenetics and Evolution 61: 801-809. doi:10.1016/j.ympev.2011.08.016.

Kawahara, A.Y. \& Breinholt, J.W. (2014) Phylogenomics provides strong evidence for relationships of butterflies and moths. Proceedings of the Royal Society B - Biological Sciences. 281: 20140970. doi: 10.1098/rspb.2014.0970.

Kyrki, J. (1984) The Yponomeutoidea: a reassessment of the superfamily and its suprageneric groups (Lepidoptera). Entomologica Scandinavica 15: 71-84.

Kyrki, J. (1988) The systematic position of Wockia Heinemann, 1870, and related genera (Lepidoptera: Ditrysia: Yponomeutoidea auct.). Nota Lepidopterologica 11: 45-69.

Moriuti, S. (1977) Fauna Japonica. Yponomeutidae s.lat. (Insecta: Lepidoptera). Keigaku Publishing Co., Tokyo, Japan: 327 pp.

Mutanen, M., Wahlberg, N. \& Kaila, L. (2010) Comprehensive gene and taxon coverage elucidates radiation patterns in moths and butterflies. Proceedings of the Royal Society B - Biological Sciences 277 (1695): 2839-2848. doi:10.1098/rspb.2010.0392.

Regier, J.C., Zwick, A., Cummings, M.P., Kawahara, A.Y., Cho, S., Weller, S., Roe, A., Baixeras, J., Brown, J.W., Parr, C., Davis, D.R., Epstein, M., Hallwachs, W., Hausmann, A., Janzen, D.H., Kitching, I.J., Solis, M.A., Yen, S.H., Bazinet, A.L. \& Mitter, C. (2009) Toward reconstructing the evolution of advanced moths and butterflies (Lepidoptera: Ditrysia): An initial molecular study. BMC Evolutionary Biology 9 (1): 280. doi:10.1186/1471-2148-9-280.

Shovkoon, D.F. (2010) A new subspecies of Hyles siehei (Püngeler) from the deserts of Central Asia (Sphingidae). Nota Lepidopterologica 33 (1): 67-79.

Sihvonen, P., Mutanen, M., Kaila, L., Brehm, G., Hausmann, A. \& Staude, H.S. (2011) Comprehensive molecular sampling yields a robust phylogeny for geometrid moths (Lepidoptera: Geometridae). PLoS ONE 6 (6): e20356. DOI:10.1371/journal.pone.0020356. 
Sinev, S.Y. (2016) A review of the little known genus Wockia (Lepidoptera: Urodidae) in Russia. Zoosystematica Rossica 25 (1): 173-179.

Sohn, J.C. (2012) Taxonomic review of Spiladarcha Meyrick (Lepidoptera: Urodoidea: Urodidae) with a new species from Venezuela. Entomological Science 15: 303-308. doi:10.1111/j.1479-8298.2012.00513.x.

Sohn, J.C. (2013) A new genus and species of Urodidae (Lepidoptera: Urodoidea) from Argentina with the first report of asymmetric male genitalia in the superfamily. Florida Entomologist 96 (2): 469-476.

Sohn, J.C. (2014a) A new genus and species of Urodidae (Lepidoptera: Urodoidea) from Sri Lanka. Journal of Asia-Pacific Entomology 17: 441-443.

Sohn, J.C. (2014b) Taxonomic review of the Neotropical genus Anchimacheta (Lepidoptera: Urodidae) with descriptions of a new congener and an allied, new genus and species from Sri Lanka. Journal of Natural History 48 (43-44): 2617-2631.

Sohn, J.C. (2014c) Two new species of Incawockia Heppner (Lepidoptera: Urodidae) from Costa Rica and Brazil. Proceedings of the Entomological Society of Washington 116 (1): 126-132.

Sohn, J.C. \& Park, K.-T. (2009) A new species of Wockia Heinemann, 1870 (Lepidoptera: Urodidae) from Vietnam. Tropical Lepidoptera Research 19 (2): 62-63.

Stehr, F.W. (1987) Order Lepidoptera. In: F. W. Stehr (Ed), Immature Insects, Vol. I. Kendall/Hunt Publishing Company, Dubuque, U.S.A.: pp. 288-596.

Wahlberg, N. \& Wheat, C.W. (2008) Genomic outposts serve the phylogenomic pioneers: Designing novel nuclear markers for genomic DNA extractions of Lepidoptera. Systematic Biology 57 (2): 231-242. doi: 10.1080/10635150802033006.

Wootton, R.J. (1979) Function, homology and terminology in insect wings. Systematic Entomology 4: 81-93.

Zahiri, R., Kitching, I.J., Lafontaine, J.D., Mutanen, M., Kaila, L., Holloway, J.D. \& Wahlberg, N. (2010) A new molecular phylogeny offers hope for a stable family-level classification of the Noctuoidea (Lepidoptera). Zoologica Scripta 40: 158-173. doi:10.1111/j.1463-6409.2010.00459.x. 